\title{
Biosynthesis of Phytoquinones
}

\author{
BIOSYNTHETIC ORIGINS OF THE NUCLEI AND SATELLITE METHYL GROUPS OF \\ PLASTOQUINONE, TOCOPHEROLS AND TOCOPHEROLQUINONES IN MAIZE \\ SHOOTS, BEAN SHOOTS AND IVY LEAVES
}

\author{
By G. R. WHISTANCE AND D. R. THRELFALL \\ Department of Biochemistry and Agricultural Biochemistry, University College of Wales, Aberystwyth
}

(Received 5 February 1968)

1. By using DL- $\left[\right.$ ring $\left.-{ }^{14} \mathrm{C}\right]$ phenylalanine, DL- $\left[\beta-{ }^{14} \mathrm{C}\right]$ phenylalanine, $\mathrm{DL}-\left[\alpha-{ }^{14} \mathrm{C}\right]-$ tyrosine and DL- $\left[\beta-{ }^{14} \mathrm{C}\right]$ tyrosine it was shown that in maize shoots (Zea mays) the nucleus and one nuclear methyl group of each of the following compounds, plastoquinone, $\gamma$-tocopherol (aromatic nucleus) and $\alpha$-tocopherolquinone, are formed from the nuclear carbon atoms and $\beta$-carbon atom respectively of either exogenous phenylalanine or exogenous tyrosine. With ubiquinone only the aromatic ring of the amino acid is used in the synthesis of the quinone nucleus. Chemical degradation of plastoquinone and $\gamma$-tocopherol molecules labelled from L-[U.14C]tyrosine established that a $\mathrm{C}_{6}-\mathrm{C}_{1}$ unit directly derived from the amino acid is involved in the synthesis of these compounds. Radioactivity from $\left[\beta-{ }^{14} \mathrm{C}\right]$ cinnamic acid is not incorporated into plastoquinone, tocopherols or tocopherolquinones, demonstrating that the $\mathrm{C}_{6}-\mathrm{C}_{1}$ unit is not formed from any of the $\mathrm{C}_{6}-\mathrm{C}_{1}$ phenolic acids associated with the metabolism of this compound. 2. The incorporation of radioactivity from $\mathrm{L}$-[U-14C]tyrosine, DL- $\left[\beta-{ }^{14} \mathrm{C}\right]$ tyrosine and $\mathrm{DL}-\left[\mathrm{U}-{ }^{14} \mathrm{C}\right]$ phenylalanine into bean shoots (Phaseolus vulgaris) and $\mathrm{DL}-\left[\beta-{ }^{14} \mathrm{C}\right]$ tyrosine and $\mathrm{L}-\left[\mathrm{Me}-{ }^{14} \mathrm{C}\right]$ methionine into ivy leaves (Hedera helix) was also investigated. Similar results were obtained to those reported for maize, except that in beans phenylalanine is only used for ubiquinone biosynthesis. This is attributed to the absence of phenylalanine hydroxylase from these tissues. In ivy leaves it is found that the $\beta$-carbon atom of tyrosine gives rise to the 8-methyl group of $\delta$-tocopherol, and it is suggested that for all other compounds examined it will give rise to the nuclear methyl group meta to the polyprenyl unit. 3. Preliminary investigations with the alga Euglena gracilis showed that in this organism ring-opening of tyrosine occurs to such an extent that the incorporation data from radiochemical experiments are meaningless. 4. The above results, coupled with previous observations, are interpreted as showing that in higher plants the nucleus of ubiquinone can be formed from either phenylalanine or tyrosine by a pathway involving as intermediates $p$-coumaric acid and $p$-hydroxybenzoic acid. Plastoquinone, tocopherols and $\alpha$-tocopherolquinone are formed from $p$-hydroxyphenylpyruvate by a pathway in which the aromatic ring and C-3 of the side chain give rise respectively to the nucleus and to one nuclear methyl group. 5. Dilution experiments provided evidence that in maize shoots $p$-hydroxyphenylpyruvic acid and homogentisic acid (produced from $p$-hydroxyphenylpyruvic acid) are involved in plastoquinone biosynthesis, and presumably the biosynthesis of related compounds: however, other possible intermediates in the conversion including toluquinol (the aglycone of the proposed key intermediate) showed no dilution effects. Further, radioactivity from $\left[M e-{ }^{14} \mathrm{C}\right]$ toluquinol is not incorporated into any of the compounds examined. 6. Dilution experiments with 3,4-dihydroxybenzaldehyde and radioactive-labelling experiments with 3,4dihydroxy[U-14 C]benzoic acid demonstrated that these compounds are not involved in the biosynthesis of either ubiquinone or phylloquinone in maize shoots. 7. Evidence is also presented to show that in maize shoots ring-opening of the aromatic amino acids takes place. The suggestion is offered that this may take place via homogentisic acid, as in animals and some micro-organisms. 
Whistance, Threlfall \& Goodwin (1967) reported on the incorporation of radioactivity from [G-14C]shikimic acid, L-[U-14C]phenylalanine, L-[U-14C]tyrosine and $p$-hydroxy[U-14C]benzoic acid into phylloquinone, plastoquinone, $\gamma$-tocopherol, $\alpha$-tocopherol, $\alpha$-tocopherolquinone and ubiquinone in maize shoots. The results were interpreted as showing : first, that the nuclei of these compounds arise by way of the shikimic acid pathway of aromatic biosynthesis; secondly, that the nucleus of ubiquinone can be formed from either phenylalanine or tyrosine by a pathway involving $p$-coumaric acid and $p$-hydroxybenzoic acid; thirdly, that plastoquinone, tocopherols and $\alpha$-tocopherolquinone are formed from $p$-hydroxyphenylpyruvic acid by a route not yet determined; fourthly, that the nucleus of phylloquinone is formed from some precursor arising early in the shikimic acid pathway.

Threlfall, Griffiths \& Goodwin (1967b) and Dada, Threlfall \& Whistance (1968) showed that the polyprenyl portions of these compounds are formed from mevalonic acid, and Threlfall, Whistance \& Goodwin $(1967 a, 1968)$ demonstrated that the methyl group of methionine is transferred intact to give the nuclear methyl group of phylloquinone, the nuclear methyl group and two methoxyl groups of ubiquinone and one or more nuclear methyl groups of plastoquinone, $\gamma$-tocopherol, $\alpha$-tocopherol and $\alpha$ tocopherolquinone. The results for the incorporation of radioactivity from $\mathrm{L}-\left[\mathrm{Me}-{ }^{14} \mathrm{C},{ }^{3} \mathrm{H}\right]$ methionine into plastoquinone, tocopherols and tocopherolquinones also led to the conclusion that one nuclear methyl group in each of these compounds is not derived from methionine (see the Results section).

In the present paper we report the results of experiments with specifically labelled aromatic amino acids and related substrates, aimed at elucidating $(a)$ the origin of the non-methionine-derived nuclear methyl group in plastoquinone, tocopherols and tocopherolquinones, and $(b)$ the biosynthetic pathways involved in the formation of the nuclei of these and related compounds in maize shoots, ivy leaves and bean leaves. Some experiments with the alga Euglena gracilis are also presented. The results of some of these investigations have been reported briefly (Whistance \& Threlfall, 1967).

For tocopherols and tocotrienols the term nucleus is used, throughout this work, to refer to the aromatic portion of the nucleus only, and does not include the carbon atoms of the heterocyclic ring that are derived from the tetraprenyl side chain.

\section{EXPERIMENTAL}

\section{Radiochemicals}

[carbonyl $-14 \mathrm{C}]$ Benzaldehyde $(1 \cdot 45 \mathrm{mc} / \mathrm{m}-\mathrm{mole}), \mathrm{L}-\left[\mathrm{Me} \cdot{ }^{14} \mathrm{C}\right]-$ methionine $(56.8 \mathrm{mc} / \mathrm{m}-\mathrm{mole}), \quad \mathrm{L}-\left[\mathrm{U}-{ }^{14} \mathrm{C}\right]$ phenylalanine $(6 \cdot 8 \mathrm{mc} / \mathrm{m} \cdot \mathrm{mole}), \quad\left[\mathrm{Me}^{-14} \mathrm{C}\right]$ toluene $\quad(10 \mathrm{mc} / \mathrm{m}-\mathrm{mole})$,
L-[U. $\left.{ }^{14} \mathrm{C}\right]$ tyrosine hydrochloride $(5.5 \mathrm{mc} / \mathrm{m}-\mathrm{mole})$ and DL - $\left[\alpha-{ }^{14} \mathrm{C}\right]$ tyrosine $(p$-hydroxyphenyl[2-14C $]$ alanine $)$ $(15.8 \mathrm{mc} / \mathrm{m}$-mole) were purchased from The Radiochemical Centre, Amersham, Bucks. DL-[ring- $\left.{ }^{14} \mathrm{C}\right]$ Phenylalanine $(3 \cdot 16 \mathrm{mc} / \mathrm{m}-\mathrm{mole}), \mathrm{DL}-\left[\beta-{ }^{14} \mathrm{C}\right]$ phenylalanine (phenyl[3.14 $\left.\mathrm{C}\right]-$ alanine) $(4.46 \mathrm{mc} / \mathrm{m}-\mathrm{mole})$ and $\mathrm{DL}-[\beta-14 \mathrm{C}]$ tyrosine $(p$ hydroxyphenyl[ $\left[3 .{ }^{14} \mathrm{C}\right]$ alanine $)(6.85 \mathrm{mc} / \mathrm{m}$-mole $)$ were purchased from the New England Nuclear Corp., Boston, Mass., U.S.A. DL-[1,2.14 $\left.\mathrm{C}_{2}\right]$ Shikimic acid $(15 \mathrm{mc} / \mathrm{m}-\mathrm{mole})$ was purchased from Calbiochem, Los Angeles, Calif., U.S.A.

The radiochemical purities of the amino acids and shikimic acid were checked by paper chromatography with the appropriate systems. DL-Phenyl[3-14 C]alanine (97\% pure, according to the suppliers) was purified by descending paper chromatography on Whatman no. 1 paper with butan-1-olacetic acid-water $(5: 1: 4$, by vol.) as developing solvent.

Chemical synthesis of [side-chain-3-14C]cinnamic acid. [side-chain-3.14C]Cinnamic acid was synthesized from [carbonyl $\left.-{ }^{14} \mathrm{C}\right]$ benzaldehyde by using a modified Perkin condensation (Bacharach \& Brogan, 1928). [carbonyl.14C]Benzaldehyde $(0.035 \mathrm{ml} ., 500 \mu \mathrm{C}), 0.2 \mathrm{ml}$. of acetic anhydride, 1 drop of pyridine and $71 \mathrm{mg}$. of anhydrous sodium acetate were refluxed for $5 \mathrm{hr}$. at $175^{\circ}$. Unchanged [carbonyl-14 $\mathrm{C}$ ]benzaldehyde was then removed by steam-distillation. The remainder of the reaction mixture was mixed with charcoal (Norit-ol), filtered and after acidification extracted four times with ether. The ethereal extracts were bulked, dried over anhydrous $\mathrm{Na}_{2} \mathrm{SO}_{4}$, filtered and evaporated to dryness. The residue was then chromatographed on thin layers of Kieselgel $G$ with benzene-dioxan-acetic acid $(90: 25: 4$, by vol.). After development the plate was sprayed with Rhodamine 6G in acetone and examined under u.v. light. The cinnamic acid, visible as a u.v.-absorbing band $\left(R_{F} 0 \cdot 4\right)$, was recovered by extraction of the gel with ether (radioscanning of the plate showed that nearly all the applied ${ }^{14} \mathrm{C}$ radioactivity was associated with the $\left[3-{ }^{14} \mathrm{C}\right]$ cinnamic acid). The yield of purified product was $10 \%$, i.e. $50 \mu \mathrm{c}$.

Chemical synthesis of $\left[\mathrm{Me}^{\left.-{ }^{14} \mathrm{C}\right] \text { toluquinol. }}\left[\mathrm{Me}^{-14} \mathrm{C}\right]\right.$. Toluquinol was synthesized from $\left[M e-{ }^{14} \mathrm{C}\right]$ toluene by using a five-stage synthesis (Scheme 1). Since the synthesis of this compound on a micro scale is extremely difficult, mainly because the intermediates are volatile and sensitive to heat and light, the full experimental procedure is given here. Before the radiochemical run was carried out each step was investigated to determine the optimum conditions; at the same time the reaction products were also fully characterized.

The first step, the mononitration of $\left[\mathrm{Me}^{-14} \mathrm{C}\right]$ toluene, was carried out in the vials in which the radiochemical was received. Two vials each containing $100 \mu \mathrm{C}$ of radioactive substrate were used. To each vial was added approx. $0 \cdot 15 \mathrm{ml}$. (10 mg.) of unlabelled toluene, to serve as carrier, followed by $1 \mathrm{ml}$. of conc. $\mathrm{HNO}_{3}$ (sp.gr. 1.42). The mixtures were then shaken for $\frac{1}{2} \mathrm{hr}$. at $40^{\circ}$. At the end of this period the reaction mixtures were diluted with $1 \mathrm{ml}$. of water, transferred to a $10 \mathrm{ml}$. stoppered test tube and extracted three times with lml. portions of light petroleum (b.p. 40-60 ${ }^{\circ}$. The light-petroleum extracts were bulked and the solvent was removed at $0^{\circ}$ in a stream of $\mathrm{O}_{2}$-free $\mathrm{N}_{2}$, to yield a yellow oil. This was then chromatographed on thin layers of Kieselgel G developed with benzene-light petroleum $(1: 4, v / v)$. This and all subsequent chromatographic procedures were carried out at $4^{\circ}$ in dim light. The mononitrotoluene band $\left(R_{F} 0 \cdot 3-0 \cdot 4\right)$, consisting of an equimolecular 


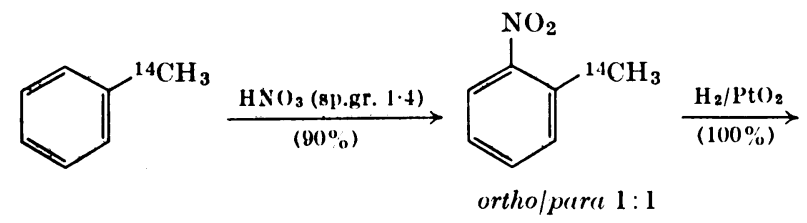<smiles>CCc1ccccc1N</smiles>

ortho/para $1: 1$

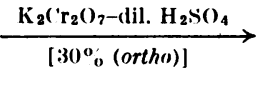

Scheme 1 .<smiles>CCC1=CC(=O)C=CC1=O</smiles>

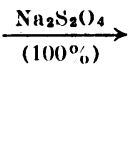<smiles>CCc1cc(O)ccc1O</smiles>

mixture of $o$ - and $p$-mononitrotoluene, was extracted with ice-cold ether. It is possible to resolve the $o$ - and $p$-isomers in this system by using low plate loadings ( $o$-isomer, $R_{F} 0 \cdot 40$; $p$-isomer, $\left.\boldsymbol{R}_{F} \mathbf{0} \cdot 36\right)$, but since the $p$-isomer does not interfere with the synthesis it was more expedient to run only one plate and recover a mixture of isomers. In trial runs the yields obtained for this reaction were in the range $75-80 \%$.

The next stage in the synthesis, the hydrogenation of the $o$ - and $p$-mononitrotoluene to give the corresponding toluidides, is on paper the simplest step. In practice it caused the greatest difficulties since the toluidides are extremely volatile and heat-labile. However, we evolved a simple procedure that leads into the subsequent reaction. The ethereal solution of mononitrotoluenes was transferred to the reaction vessel of a microhydrogenator (A. Gallenkamp and Co. Ltd., Widnes, Lancs.), and the ether removed at $0^{\circ}$ in a stream of $\mathrm{O}_{2}$-free $\mathrm{N}_{2}$. The sample was then dissolved in $5 \mathrm{ml}$. of cyclohexane and hydrogenated for $3 \mathrm{hr}$. with $\mathrm{PtO}_{2}$ (10 mg.) as catalyst. (The hydrogenation reaction goes to completion and no purification of the product is required.) At the end of this period the reaction mixture was trans. ferred to a $10 \mathrm{ml}$. stoppered test tube and extracted twice with $0.3 \mathrm{ml}$. portions of $5 \mathrm{~N}-\mathrm{H}_{2} \mathrm{SO}_{4}$. The acid extracts, containing hydrogen sulphates of $o$ - and $p$-toluidide, were combined for the next step.

The combined extracts $(0.6 \mathrm{ml}$.) were cooled in ice and $26 \mathrm{mg}$. of $\mathrm{K}_{2} \mathrm{Cr}_{2} \mathrm{O}_{7}$ was added: the mixture was then stirred with a glass rod for $15 \mathrm{~min}$. A further $26 \mathrm{mg}$. of $\mathrm{K}_{2} \mathrm{Cr}_{2} \mathrm{O}_{7}$ was then added and the mixture allowed to warm up to room temperature. Stirring was continued for a further $45 \mathrm{~min}$. Under these conditions o-toluidide is oxidized to tolu. quinone. The reaction mixture was then diluted with water ( $2 \mathrm{ml}$.) and extracted four times with $1 \mathrm{ml}$. portions of ether. The ethereal extracts containing the toluquinone were combined, concentrated and chromatographed on thin layers of Kieselgel G (impregnated with Rhodamine 6G) developed with chloroform. Toluquinone $\left(R_{F} 0 \cdot 6\right)$ was recovered by extraction of the gel with ether. The yields obtained for this step were extremely variable, ranging from 10 to $50 \%$. However, despite the low yield, the ether extracts of the reaction mixture contained toluquinone as the principal radiochemical component.

The final stage in the synthesis is the reduction of toluquinone to toluquinol. The ethereal extract of toluquinone was made up to $20 \mathrm{ml}$. and shaken vigorously for $5 \mathrm{~min}$. with $20 \mathrm{ml}$. of water containing excess of $\mathrm{Na}_{2} \mathrm{~S}_{2} \mathrm{O}_{4}$. The ethereal layer was dried over anhydrous $\mathrm{Na}_{2} \mathrm{SO}_{4}$, filtered and evaporated to dryness at $0^{\circ}$ in a stream of $\mathrm{O}_{2}$-free $\mathrm{N}_{2}$. The quinol was then chromatographed on thin layers of Kieselgel G (impregnated with Rhodamine 6G) developed with diisopropyl ether-benzene $(1: 4, \mathrm{v} / \mathrm{v})$. Toluquinol $\left(R_{F} 0 \cdot 2\right)$ was recovered by elution with ether. The yield (spectrophotometric determination) was $3.63 \mathrm{mg}$. and the specific radioactivity was $5 \cdot 5 \mu \mathrm{c} / \mathrm{mg}$. The overall yield was $20 \%$ after allowing for the mixture of $o$ - and $p$-isomers of nitrotoluene.

The toluquinol was stored in water $(10 \mathrm{ml}$.) containing ascorbic acid $(10 \mathrm{mg}$.). The latter serves to keep it in the reduced state. In the absence of ascorbic acid toluquinol is rapidly reoxidized to toluquinone in the dark; in the absence of ascorbic acid a brown decomposition product is formed in the light.

Enzymic synthesis of 3,4-dihydroxy[U.14C]benzoic acid. 3,4-Dihydroxy[U.14 C]benzoic acid $(4 \cdot 28 \mathrm{mc} / \mathrm{m}$-mole) was prepared by enzymic hydroxylation (Hacking, 1967) of 4-hydroxy[U.14C]benzoic acid (prepared by alkaline fusion of L-[U-14C]tyrosine hydrochloride; Parson \& Rudney, 1964). The enzyme used was $p$-hydroxybenzoate hydroxylase isolated from Pseudomonas putida, strain A3.12 (A.T.C.C. 12633), and the method was that described by Hosokawa \& Stanier (1966).

\section{Chemicals}

3,4-Dihydroxybenzaldehyde, gentisic acid, $p$-hydroxyphenylpyruvic acid and DL-tyrosine were purchased from British Drug Houses Ltd., Poole, Dorset. Toluquinone and L-tyrosine were purchased from Hopkin and Williams Ltd., London, E.C. 1. Toluquinol was purchased from KochLight Laboratories Ltd., Colnbrook, Bucks. Gentisaldehyde was purchased from Ralph Emanuel Ltd., London, S.E.1. Homogentisic acid was a gift from Dr H. Hassal, Department of Biochemistry, University of Leeds.

It was found necessary to purify the gentisaldehyde before use. This was done by quantitative chromatography on thin layers of Kieselgel G (impregnated with Rhodamine 6G) developed with ethyl acetate-benzene $(1: 4, v / v)$. In this system gentisaldehyde has $R_{F} 0 \cdot 4$. 
All other chemicals used were of AnalaR or equivalent grade.

Synthesis of gentisyl alcohol. This was prepared by reduction of gentisaldehyde in ethanol with zinc and conc. $\mathrm{HCl}$.

Solvents. The purification of solvents used for extraction, chromatographic and spectroscopic purposes was as described by Threlfall \& Goodwin (1967).

\section{Biological methods}

Biological material. Seeds of Zea mays (var. Rhodesian White Double Hybrid) and Phaseolus vulgaris (var. Carters Lightning Dwarf French Bean) were purchased from Hurst, Gunson, Cooper and Taber Ltd., Witham, Essex, and Carters Tested Seeds, London, S.W. 20, respectively. Leaves of Hedera helix were collected locally during November 1966 to January 1967. The culture of Euglena gracilis strain $\mathrm{Z}$ was obtained from the Culture Collection of Algae and Protozoa, Cambridge.

Cultivation of seedlings. Etiolated 6-7-day-old seedlings of maize were grown as described by Griffiths, Threlfall \& Goodwin (1967). French-bean seeds were soaked in water for $12 \mathrm{hr}$., sown in soil (John Innes compost no. 1) and allowed to germinate for 12 days at $26^{\circ}$ in the dark. At the end of this period the plants were $15 \mathrm{~cm}$. tall.

Culture of Euglena gracilis. Euglena gracilis was grown in shake culture on the autotrophic medium of Pringsheim \& Pringsheim (1952). The cultures were grown for 4 days at $28^{\circ}$ in the light. For each experiment 11. of medium dispensed in four 11. conical flasks was used.

Exposure of biological material to ${ }^{14} \mathrm{C}$-labelled substrates. Etiolated maize shoots were excised and exposed to radioactive substrates under the conditions described by Whistance et al. (1967). Etiolated beans were excised at soil level and, after removal of the cotyledons, the cut ends of the shoots (120/experiment) were dipped in water $(100 \mathrm{ml}$.) containing the ${ }^{14} \mathrm{C}$-labelled substrate. The shoots were then exposed to continuous illumination (300lumens/ft. ${ }^{2}$ ) for $24 \mathrm{hr}$. at $26^{\circ}$.

Ivy leaves were collected on the day of the experiment. The radioactive substrate was administered by dipping the leaves in an aqueous solution $(25 \mathrm{ml}$.) of the radiochemical containing Tween $80(0 \cdot 1 \%)$. The incubation was carried out by spreading the leaves on a large glass plate and illuminating them for $6 \mathrm{hr}$. at room temperature.

In experiments with plant tissues, ${ }^{14} \mathrm{C}$-labelled aromatic amino acids were administered as their hydrochlorides. $\mathrm{DL}-\left[1,2-{ }^{14} \mathrm{C}_{2}\right]$ Shikimic acid, [side-chain-3-14 $\left.\mathrm{C}\right]$ cinnamic acid and 3,4-dihydroxy[U-14 C] benzoic acid were administered as the free acids. In dilution studies $p$-hydroxyphenylpyruvic acid, gentisic acid, gentisaldehyde, gentisyl alcohol, 3,4dihydroxybenzaldehyde, L-tyrosine hydrochloride and DL-tyrosine hydrochloride were added to an aqueous solution of the ${ }^{14} \mathrm{C}$-labelled aromatic amino acid hydrochloride. $\left[M e-{ }^{14} \mathrm{C}\right]$ Toluquinol and unlabelled toluquinol (in dilution studies) were administered in water containing ascorbic acid $(50 \mathrm{mg} . / 100 \mathrm{ml}$. incubation). The ascorbic acid prevented the photo-destruction of toluquinol.

Euglena gracilis was harvested by centrifugation, resuspended in $100 \mathrm{ml}$. of $0.04 \mathrm{M}$-sodium phosphate buffer, pH 6.7, containing the radioactive substrate and exposed with shaking to continuous illumination (300lumens/ft. ${ }^{2}$ ) for $6 \mathrm{hr}$. at $28^{\circ}$.

\section{Analytical methods}

Extraction and preliminary purification of lipid. Higherplant tissues were extracted by the procedure of Griffiths et al. (1967). Cells of Euglena gracilis were harvested by centrifugation and the lipid was extracted as described by Threlfall \& Goodwin (1967).

The lipids were resolved into various terpenoid-containing fractions by column chromatography on acid-washed alumina (Brockmann grade III) (Woelm; anionotropic), developed by stepwise elution with $0.25 \%, 1 \%, 3 \%, 5 \%$, $8 \%, 12 \%$ and $20 \%(\mathrm{v} / \mathrm{v}) \mathrm{E} / \mathrm{P}^{*}$ as described by Griffiths et al. (1967) (see also Table 1).

Purification procedures. The purification of squalene, $\beta$-carotene, phylloquinone, plastoquinone, ubiquinone, $\gamma$-tocopherol, $\alpha$-tocopherol, $\alpha$-tocopherolquinone, sterol esters and $3 \beta$-hydroxy sterols was carried out as described by Whistance et al. (1967).

Purification of $\delta$-tocopherol from ivy. This compound is contained in the $8 \%-\mathrm{E} / \mathrm{P}$ fraction obtained from preliminary column chromatography of the lipid extract. The fraction was first chromatographed on thin layers (Kieselgel G) with ethyl acetate-benzene $(3: 22, \mathrm{v} / \mathrm{v})$ as the developing solvent $\left(R_{F} 0 \cdot 46\right)$. The recovered chromanol was then further purified by thin-layer chromatography with the following sequence: reversed phase, aq. $80 \%(\mathrm{v} / \mathrm{v})$ acetone $\left(R_{F} 0 \cdot 49\right)$; benzene-chloroform $(1: 1, \mathrm{v} / \mathrm{v}) \quad\left(R_{F} 0.22\right)$; di-isopropyl ether-benzene $(1: 4, \mathrm{v} / \mathrm{v})\left(R_{F} 0 \cdot 40\right)$.

Examination of sterol esters. Sterol esters of maize were obtained by using the procedures described by Threlfall $e t$ al. $(1967 b)$. The samples were saponified and the sterols recovered by extraction with ether (Threlfall et al. 1967b). The saponification mixture was then acidified to $\mathrm{pH} 2$ and the fatty acids were extracted with ether. After assay of both samples for radioactivity the sterol fraction was further investigated by chromatography on Kieselgel G plates developed with ethyl acetate-benzene $(1: 4, \mathrm{v} / \mathrm{v})$. This system separates the sterols into three classes: $3 \beta$ hydroxy sterols $\left(R_{F} 0 \cdot 25\right), 4 \alpha$-methyl sterols $\left(R_{F} 0 \cdot 4\right)$ and 4,4-dimethyl sterols $\left(R_{F} 0 \cdot 55\right)$. $3 \beta$-Hydroxy sterols were recovered and assayed for radioactivity.

Degradation of plastoquinone, ubiquinone, $\gamma$-tocopherol and $\alpha$-tocopherolquinone (Scheme 2). Radioactivity in the nonaprenyl side chains of plastoquinone and ubiquinone-9 was determined by ozonolytic degradation (Whistance et al. 1967).

Radioactivity in the nuclear methyl groups of plastoquinone, $\gamma$-tocopherol and $\alpha$-tocopherolquinone was determined by Kuhn-Roth oxidation followed by a Schmidt degradation (Threlfall et al. 1968). This procedure is only valid for determining the radioactivity in nuclear methyl groups if radioactivity is essentially absent from the polyprenyl unit of the compound under investigation.

Spectrophotometry. $\beta$-Carotene, phylloquinone, plastoquinone, $\gamma$-tocopherol, $\alpha$-tocopherol, $\alpha$-tocopherolquinone and ubiquinone were assayed by the procedures of Threlfall \& Goodwin (1967) and Whistance et al. (1967). $\delta$-Tocopherol was assayed in cyclohexane. The $E_{1}^{1 \%} \mathrm{~cm}$. $(295 \mathrm{~m} \mu)$ value used was 93.8 (Whittle, Dunphy \& Pennock, 1966).

Radioassay. Details of scintillation counting, proportional counting, scanning of thin-layer chromatograms

* Abbreviation: $\mathrm{E} / \mathrm{P}$, solution of diethyl ether in light petroleum (b.p. $40-60^{\circ}$ ). 
and radioautography were as described by Whistance et al. (1967) and Threlfall et al. (1968). All counts were corrected for background and instrument efficiency.

\section{RESULTS}

\section{Experiments with maize shoots}

Incorporation of radioactivity from $\mathrm{DL}-\left[\right.$ ring $\left.-{ }^{14} \mathrm{C}\right]$. phenylalanine, $\mathrm{DL}-\left[\beta-{ }^{14} \mathrm{C}\right]$ phenylalanine, $\mathrm{DL}-\left[\alpha-{ }^{14} \mathrm{C}\right]-$ tyrosine, DL- $\left[\beta-{ }^{14} \mathrm{C}\right]$ tyrosine and [side-chain-3-14C]cinnamic acid. Whistance et al. (1967) found that, on incubation of excised etiolated maize shoots with either L-[U-14C]phenylalanine or L-[U-14C]tyrosine, radioactivity was incorporated into plastoquinone, $\gamma$-tocopherol, $\alpha$-tocopherolquinone and ubiquinone. From this it was concluded that the aromatic nuclei of these amino acids were giving rise to the $p$-benzoquinone nuclei and the aromatic portions of the chromanol nuclei. We also concluded, on the basis of comparing the specific radioactivities

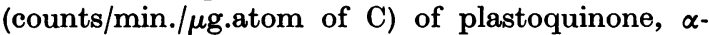

tocopherolquinone, tocopherols and phylloquinone (reference compound) when maize shoots were supplied with $\mathrm{L}-\left[M e-{ }^{14} \mathrm{C},{ }^{3} \mathrm{H}\right]$ methionine (Threlfall et al. 1968) and other substrates, that in plastoquinone, $\alpha$-tocopherolquinone and tocopherols one nuclear methyl group was not derived from the methyl group of methionine.

The most likely source of the non-methioninederived nuclear methyl groups of plastoquinone, tocopherols and $\alpha$-tocopherolquinone appeared to be the $\beta$-carbon atom of tyrosine. To investigate this possibility etiolated maize shoots were exposed for $24 \mathrm{hr}$. with continuous illumination to $\mathrm{DL}$ $\left[\right.$ ring- $\left.{ }^{14} \mathrm{C}\right]$ phenylalanine, DL- $\left[\beta-{ }^{14} \mathrm{C}\right]$ phenylalanine, DL- $\left[\alpha-{ }^{14} \mathrm{C}\right]$ tyrosine or DL- $\left[\beta-{ }^{14} \mathrm{C}\right]$ tyrosine. This experimental system has been described fully by Griffiths et al. (1967).

Table 1 summarizes the incorporation of radioactivity from the various substrates into fractions obtained from preliminary chromatography of the lipid extracts. Included in Table 1, for purposes of

Table 1. Incorporation by maize shoots of radioactivity from uniformly and specifically ${ }^{14} \mathrm{C}$-labelled aromatic amino acids and [side-chain-3-14C]cinnamic acid into fractions obtained from column chromatography of the lipid extracts

Etiolated 7-day-old maize shoots were excised and exposed with continuous illumination to the appropriate radioactive substrate for $24 \mathrm{hr}$. Total lipids were extracted and chromatographed on columns of Brockmann grade III acid-washed alumina (Woelm) developed by stepwise elution with light petroleum (b.p.40-60 ${ }^{\circ}$ ) containing increasing amounts of ether. The values obtained when U-14C-labelled L-substrates $(20 \mu \mathrm{C}$ each) were administered are given in parentheses. N.D., Not determined.

Radioactivity (counts/min.)

\begin{tabular}{|c|c|c|c|c|}
\hline $\begin{array}{c}\text { DL- }[\text { ring- } 14 \mathrm{C}]- \\
\text { Phenylalanine } \\
(300 \text { shoots } \\
\text { incubated with } \\
20 \mu \mathrm{c})\end{array}$ & $\begin{array}{c}\text { DL- }\left[\beta-{ }^{14} \mathrm{C}\right]- \\
\text { Phenylalanine } \\
\text { (200 shoots } \\
\text { incubated with } \\
20 \mu \mathrm{c})\end{array}$ & $\begin{array}{c}\text { DL- }\left[\beta-{ }^{14} \mathrm{C}\right]- \\
\text { Tyrosine } \\
\text { (300 shoots } \\
\text { incubated } \\
\text { with } 20 \mu \mathrm{c})\end{array}$ & $\begin{array}{c}\text { DL }\left[\alpha-{ }^{14} \mathrm{C}\right]- \\
\text { Tyrosine } \\
(200 \text { shoots } \\
\text { incubated } \\
\text { with } 10 \mu \mathrm{C})\end{array}$ & $\begin{array}{c}\text { [side-chain-3-14C]- } \\
\text { Cinnamic acid } \\
(200 \text { shoots } \\
\text { incubated } \\
\text { with } 5 \mu \mathrm{c})\end{array}$ \\
\hline 1255 & $1149(3210)$ & 48050 ( & 10 & 18850 \\
\hline
\end{tabular}

$(\% \mathrm{E} / \mathrm{P})$

$\mathbf{0 . 2 5}$

2635

2190

3

5

2570

8

12

1454

20

560

$0 \cdot 03$

Radio-

activity

in column

fractions

(\% of dose

given)
Terpenoids present

$\begin{array}{lc}\text { Nature } & \begin{array}{c}\text { Amount } \\ (\mu \mathrm{g} . / 100 \text { shoots })\end{array} \\ \beta \text {-Carotene } & 50-150 \\ \text { Squalene } & \text { N.D. } \\ \text { Phylloquinone } & 50-70 \\ \text { Plastoquinone } & 500-700 \\ \text { Sterol esters } & \text { N.D. } \\ \alpha \text {-Tocopherol } & 150-200 \\ \gamma \text {-Tocopherol } & 30-60 \\ \text { Ubiquinone-9 } & 150-200\end{array}$

$\begin{array}{lc}\begin{array}{l}3 \beta \text {-Hydroxy } \\ \text { sterols }\end{array} & 18(\mathrm{mg} .)-20(\mathrm{mg} .) \\ \begin{array}{l}\alpha \text {-Tocopherol- } \\ \text { quinone }\end{array} & 80-120\end{array}$


Table 2. Incorporation by maize shoots of $\mathrm{DL}-\left[\right.$ ring $\left.{ }^{14} \mathrm{C}\right]$ phenylalanine, $\mathrm{DL}-\left[\beta-{ }^{14} \mathrm{C}\right]$ phenylalanine, $\mathrm{DL}-\left[\alpha-{ }^{14} \mathrm{C}\right]$ tyrosine, $\mathrm{DL}-\left[\beta-{ }^{14} \mathrm{C}\right]$ tyrosine and $[$ side-chain-3-14C $]$ cinnamic acid into terpenoid quinones and chromanols

Etiolated 7-day-old maize shoots were excised and exposed with continuous illumination to the appropriate radioactive substrate for $24 \mathrm{hr}$. N.D., Not determined.

Specific radioactivity (counts $/ \mathrm{min} . / \mu$ mole)

\begin{tabular}{|c|c|c|c|c|c|c|}
\hline Terpenoid & $\begin{array}{c}\left.\text { DL-[ring- }{ }^{14} \mathrm{C}\right]- \\
\text { Phenylalanine } \\
(3 \cdot 16 \mathrm{mc} / \mathrm{m}-\mathrm{mole}) \\
(300 \text { shoots } \\
\text { incubated with } \\
20 \mu \mathrm{C})\end{array}$ & $\begin{array}{c}\text { DL- }[\beta-14 \mathrm{C}]- \\
\text { Phenylalanine } \\
(4 \cdot 46 \mathrm{mc} / \mathrm{m}-\mathrm{mole}) \\
(200 \text { shoots } \\
\text { incubated with } \\
20 \mu \mathrm{C})\end{array}$ & $\begin{array}{c}\text { DL- }[\alpha-14 \mathrm{C}]- \\
\text { Tyrosine } \\
(15 \cdot 8 \mathrm{mc} / \mathrm{m}-\mathrm{mole}) \\
(200 \text { shoots } \\
\text { incubated with } \\
10 \mu \mathrm{c})\end{array}$ & $\begin{array}{c}\text { DL- }[\beta-14 \mathrm{C}]- \\
\text { Tyrosine } \\
(6 \cdot 85 \mathrm{mc} / \mathrm{m}-\mathrm{mole}) \\
(300 \text { shoots } \\
\text { incubated with } \\
20 \mu \mathrm{c})\end{array}$ & $\begin{array}{r}\text { [side-c } \\
\text { Cinn } \\
(1 \cdot 451 \\
(20 \\
\text { incu }\end{array}$ & $\begin{array}{l}\text { chain-3-14C]- } \\
\text { lamic acid } \\
\text { mc/m-mole) } \\
00 \text { shoots } \\
\text { bated with } \\
5 \mu \mathrm{c})\end{array}$ \\
\hline \multicolumn{7}{|l|}{ Intrachloroplastidic } \\
\hline$\beta$-Carotene & $\mathbf{0}$ & $\mathbf{0}$ & 277 & 219 & & $\mathbf{0}$ \\
\hline Phylloquinone & $\mathbf{0}$ & 0 & 120 & 180 & & 0 \\
\hline Plastoquinone & 745 & 836 & 118 & 82800 & & 0 \\
\hline$\gamma$-Tocopherol & 1737 & $786^{*}$ & 367 & 146000 & & 0 \\
\hline$\alpha$-Tocopherol & Absent & Absent & Absent & Absent & & $\mathbf{0}$ \\
\hline$\alpha$-Tocopherolquinone & 727 & 845 & 189 & 69700 & & $\mathbf{0}$ \\
\hline \multicolumn{7}{|l|}{ Extrachloroplastidic } \\
\hline Squalene & 0 & $\mathbf{0}$ & 1415 (counts/min.) & N.D. & & 0 \\
\hline Sterol esters & N.D. & N.D. & 1086 (counts/min.) & $\dagger 70800$ (counts/ & $\min .) \dagger$ & 0 \\
\hline $3 \beta$-Hydroxy sterols & 5 & 17 & 938 & 1396 & & 35 \\
\hline Ubiquinone-9 & 2070 & 139 & 2448 & 4200 & & 78 \\
\hline
\end{tabular}

* Low specific radioactivity because a different strain of maize was used in this experiment.

$\dagger$ All the radioactivity was in the sterol portions of the molecules.

comparison, are the results obtained when either $\mathrm{L}-\left[\mathrm{U}-{ }^{14} \mathrm{C}\right]$ phenylalanine or $\mathrm{L}-\left[\mathrm{U}-{ }^{14} \mathrm{C}\right]$ tyrosine was administered. The specific radioactivities of the purified compounds are given in Table 2. For ease of interpretation, they are listed as either intrachloroplastidic or extrachloroplastidic. Although the intracellular distribution of $\gamma$-tocopherol has not been convincingly demonstrated it is included with the intrachloroplastidic components, since its behaviour towards the various radioactive substrates parallels that of the other components of this group. $\alpha$-Tocopherol, a component normally present in maize shoots, was found in these experiments to be either present in extremely small amounts or entirely absent.

Incorporation of radioactivity into terpenoidcontaining fractions obtained from chromatography of the lipid extracts was low, ranging from $0.02 \%$ to $2.8 \%$ of the dose administered (Table 1). Nevertheless, except in the experiment with $\mathrm{DL}-\left[\alpha-{ }^{14} \mathrm{C}\right]$ tyrosine, radioactivity was incorporated in a specific manner into plastoquinone, $\gamma$-tocopherol and $\alpha$ tocopherolquinone (see below). Except for plastoquinone, the quinones and chromanols never contained a major part of the radioactivity in any one fraction (Tables 1 and 2). Indeed, in the $5 \%-\mathrm{E} / \mathrm{P}$ and $12 \%-\mathrm{E} / \mathrm{P}$ fractions most of the radioactivity was present in sterol precursors and $3 \beta$. hydroxy sterols respectively, showing that catabolism of the administered radioactive substrates to give metabolites capable of entering the biosynthetic sequences leading to isoprenoid formation had occurred.

Although radioactivity was present in the terpenoid reference compounds isolated and hence in the polyprenyl side chains of the quinones and chromanols examined, it is possible, by using the specific-radioactivity data, to determine whether the radioactivity in a molecule represents a specific or a general incorporation. Thus in numerous experiments we have found that the specific radioactivity (counts/min./ $\mu$ mole) of $\beta$-carotene reflects the radioactivity (counts $/ \mathrm{min} . / \mu$ mole) in the polyprenyl side chains of the intrachloroplastidic components, and that the specific radioactivity (counts/min./ $\mu$ mole) of $3 \beta$-hydroxy sterols multiplied by 2-4 gives a fair estimate of the radioactivity (counts/min./ $\mu$ mole) in the nonaprenyl side chain and nuclear methyl and methoxyl substituents of ubiquinone. Obviously when one of the quinone components of the intrachloroplastidic group is completely or nearly non-radioactive, then high levels of radioactivity in the other components of the group cannot be associated with either the polyprenyl side chains or methionine-derived methyl groups. 
Examination of the specific-radioactivity data (Table 2) showed that, when DL-[ring- $\left.{ }^{14} \mathrm{C}\right]$ phenylalanine, DL- $\left[\beta-{ }^{14} \mathrm{C}\right]$ phenylalanine or DL- $\left[\beta-{ }^{14} \mathrm{C}\right]$ tyrosine was administered, radioactivity was incorporated in a specific manner into plastoquinone, $\gamma$-tocopherol and $\alpha$-tocopherolquinone. With DL[ring $\left.-{ }^{14} \mathrm{C}\right]$ phenylalanine a specific incorporation into ubiquinone was also observed. The specific radioactivities of the compounds isolated from maize shoots incubated with DL- $\left[\alpha-{ }^{14} \mathrm{C}\right]$ tyrosine were consistent with a general incorporation of radioactivity from this substrate. These results, coupled with our previous observations (Whistance et al. 1967), led us to the conclusion that the nuclear carbon atoms and $\beta$-carbon atoms of exogenous phenylalanine and tyrosine were utilized by maize shoots for the biosynthesis of plastoquinone, $\gamma$-tocopherol and $\alpha$ - tocopherolquinone, only the ring portion of these amino acids being used for ubiquinone biosynthesis.

The results of the various chemical degradation procedures showed clearly that with plastoquinone, $\gamma$-tocopherol and $\alpha$-tocopherolquinone radioactivity from $D L-\left[\beta-{ }^{14} \mathrm{C}\right]$ tyrosine was incorporated into nuclear methyl groups (Table 3). In ubiquinone samples labelled from $\mathrm{DL}-\left[\beta-{ }^{14} \mathrm{C}\right]$ tyrosine substrate, as well as from $\mathrm{DL}-\left[\alpha-{ }^{-14} \mathrm{C}\right]$ tyrosine, radioactivity was confined almost entirely to the nonaprenyl side chain.

On degradation of the plastoquinone and $\gamma$-tocopherol samples isolated from an $\mathrm{L}-\left[\mathrm{U}-{ }^{14} \mathrm{C}\right]$ tyrosine incubation all the radioactivity could be accounted for in the nuclei and nuclear methyl groups (Table 3). The finding that on Kuhn-Roth oxidation of these samples $43 \%$ of the total radioactivity in the

Table 3. Chemical degradation of quinone and chromanol samples isolated from maize shoots exposed to $\mathrm{DL}-\left[\beta-{ }^{14} \mathrm{C}\right]$ tyrosine, DL- $\left[\alpha-{ }^{14} \mathrm{C}\right]$ tyrosine, $\mathrm{L}-\left[\mathrm{U}-{ }^{14} \mathrm{C}\right]$ tyrosine and $\left[1,2 \cdot{ }^{14} \mathrm{C}_{2}\right]$ shikimic acid

The distribution of radioactivity in the quinone and chromanol molecules was determined by using the procedures listed below. L-[U.14C]Tyrosine samples were obtained by incubating etiolated maize shoots (300) under our standard conditions with $20 \mu \mathrm{C}$ of radioactive substrate.

Kuhn-Roth oxidation

\begin{tabular}{|c|c|c|c|c|c|c|c|c|c|c|c|}
\hline & & & & & & & & & & & \\
\hline & & & & & & & & Radioa & ctivity ir & n sodium & acetate \\
\hline & & & Ozo & onolytic d & degradatic & ion & & & & Schmidt & degrada- \\
\hline & & & & & $\begin{array}{l}\text { Radioac } \\
\text { prenyl sid }\end{array}$ & $\begin{array}{l}\text { ctivity in } \\
\text { de chain* }\end{array}$ & & & & $\begin{array}{r}\text { persul } \\
\text { oxida }\end{array}$ & $\begin{array}{l}\text { lphate } \\
\text { ation }\end{array}$ \\
\hline Substrate & $\begin{array}{r}\mathrm{S} \\
\mathrm{r} \\
\mathrm{ac} \\
(\mathrm{cc} \\
\mathrm{n} \\
\mathrm{r}\end{array}$ & $\begin{array}{l}\text { Specific At } \\
\text { radio- } \\
\text { activity } \\
\text { counts/ } \\
\text { min./ } \\
\text { mg.) }\end{array}$ & 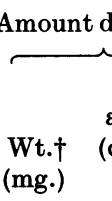 & $\begin{array}{c}\text { degraded } \\
\text { Radio- } \\
\text { activity } \\
\text { (counts/ } \\
\text { min.) }\end{array}$ & $\begin{array}{c}\text { (counts/ } \\
\text { min.) }\end{array}$ & $\begin{array}{c}\text { (\% of } \\
\text { total } \\
\text { radio- } \\
\text { activity } \\
\text { in mole- } \\
\text { cule) }\end{array}$ & $\begin{array}{l}\text { Amount } \\
\text { degraded } \\
\text { (counts/ } \\
\text { min.) }\end{array}$ & $\begin{array}{l}\text { (counts } \\
\text { min.) }\end{array}$ & $\begin{array}{c}\text { (\% of } \\
\text { total } \\
\text { radio- } \\
\text { activity } \\
\text { in mole } \\
\text { cule) }\end{array}$ & $\begin{array}{l}\text { (\% of } \\
\text { radio- } \\
\text { activity } \\
\text { y in } \\
\text { carboxyl } \\
\text { group) }\end{array}$ & $\begin{array}{l}\text { (\% of } \\
\text { radio- } \\
\text { activity } \\
\text { in } \\
\text { methyl } \\
\text { group) }\end{array}$ \\
\hline $\mathrm{DL}-\left[\beta{ }^{14} \mathrm{C}\right]-$ & Plastoquinone & 110700 & $1 \cdot 05$ & 19600 & 51 & $0 \cdot 3$ & 19100 & 18900 & 99 & 0 & 94 \\
\hline Tyrosine & $\gamma$-Tocopherol & $\mathbf{3 3 8 0 0 0}$ & - & - & - & $\begin{array}{l}<2 \text { (by } \\
\text { diff.) }\end{array}$ & 6615 & 6475 & 98 & 0 & 97 \\
\hline & $\begin{array}{l}\alpha \text {-Tocopherol- } \\
\text { quinone }\end{array}$ & 156200 & - & - & - & $\begin{array}{l}\mathbf{0} \text { (by } \\
\text { diff.) }\end{array}$ & 3448 & 3720 & 108 & 0 & 95 \\
\hline & Ubiquinone-9 & 5275 & $1 \cdot 08$ & 1292 & 1202 & 93 & - & - & - & - & - \\
\hline $\mathrm{L}-\left[\mathrm{U}-{ }^{14} \mathrm{C}\right]-$ & Plastoquinone & 6200 & 0.72 & 4464 & 22 & 0.5 & 6820 & 2980 & 44 & 64 & 32 \\
\hline Tyrosine & $\gamma$-Tocopherol & 21000 & - & - & - & $\begin{array}{c}<2 \\
\text { (calc.) }\end{array}$ & 1897 & 800 & 42 & 65 & 30 \\
\hline & Ubiquinone-9 & 10800 & $0 \cdot 15$ & 1620 & 48 & 3 & 2450 & 398 & 16 & 98 & 0 \\
\hline $\begin{array}{r}\text { DL }-\left[\alpha-{ }^{14} \mathrm{C}\right] \\
\text { Tyrosine }\end{array}$ & Ubiquinone-9 & 3075 & 0.21 & 680 & 687 & 101 & - & 一 & - & - & - \\
\hline $\begin{array}{l}{\left[1,2-14 \mathrm{C}_{2}\right]-} \\
\text { Shikimic } \\
\text { acid }\end{array}$ & Plastoquinone $\ddagger$ & 29800 & - & - & - & - & 5894 & 1223 & 21 & 93 & 0 \\
\hline
\end{tabular}




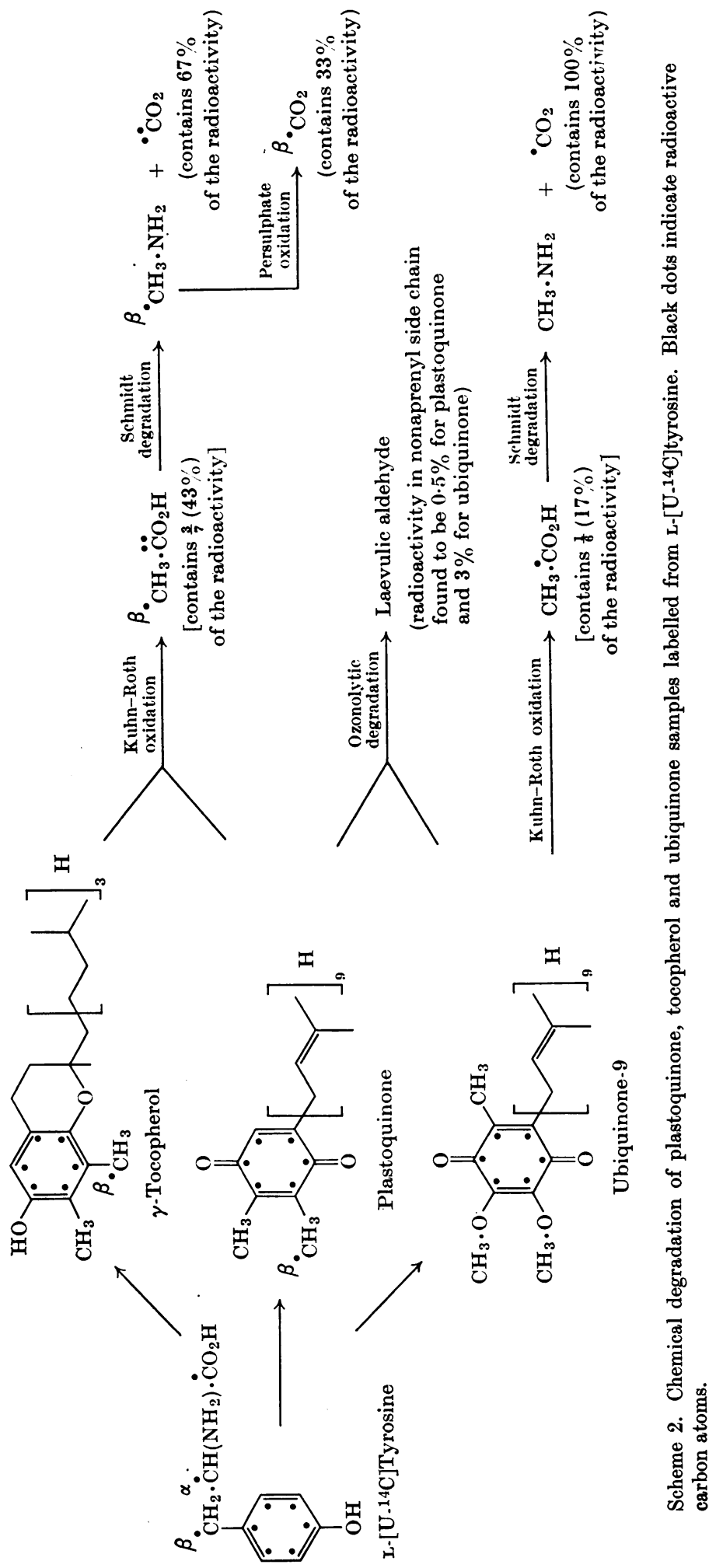


molecules was recovered in the acetic acid fraction, and that $33 \%$ of this radioactivity was in the methyl group, demonstrates clearly that the $\mathrm{C}_{6}-\mathrm{C}_{1}$ unit incorporated into these compounds arises directly from tyrosine (Table 3 and Scheme 2). In ubiquinone labelled from $\mathrm{L}$-[U-14C]tyrosine all the radioactivity was in the ring carbon atoms; KuhnRoth oxidation showed that this radioactivity was uniformly distributed (Table 3 and Scheme 2).

To obtain more information about the general metabolism of tyrosine by maize shoots the incorporation of radioactivity from $\mathrm{DL}-\left[\alpha-{ }^{14} \mathrm{C}\right]$ tyrosine and $\mathrm{DL}-\left[\beta-{ }^{14} \mathrm{C}\right]$ tyrosine into sterol esters was investigated (Table 2). In both cases it was found that most of the radioactivity associated with these esters was in the sterol portion, showing that the metabolism of $\mathrm{DL}-\left[\alpha-{ }^{14} \mathrm{C}\right]$ tyrosine and $\mathrm{DL}-\left[\beta-{ }^{14} \mathrm{C}\right]$ tyrosine gave rise to a small radioactive molecule that was an effective precursor for terpenoid biosynthesis but not for fatty acid biosynthesis.

Previously we have suggested that the $\mathrm{C}_{6}-\mathrm{C}_{1}$ compound involved in plastoquinone, tocopherol and tocopherolquinone biosynthesis arises from tyrosine (or more precisely $p$-hydroxyphenylpyruvic acid) by a metabolic sequence so far never reported for plants, i.e. via homogentisic acid (Whistance \& Threlfall, 1967). To eliminate the possibility that the $\mathrm{C}_{6}-\mathrm{C}_{1}$ unit involved is not de- rived from any of the many $\mathrm{C}_{6}-\mathrm{C}_{3}$ or $\mathrm{C}_{6}-\mathrm{C}_{1}$ phenolic acids formed from the deamination products of either phenylalanine (cinnamic acid) or tyrosine ( $p$-coumaric acid), maize shoots were incubated with [side-chain-3 ${ }^{14} \mathrm{C}$ ] cinnamic acid. Radioactivity from this substrate was not specifically incorporated into any of the quinones and chromanols examined (Tables 1 and 2).

Dilution experiments. In the previous experiments it was observed that radioactivity from $\mathrm{DL}-\left[\beta-{ }^{14} \mathrm{C}\right]$ tyrosine was incorporated into the lipid fractions and into the quinones and chromanols far more effectively than when L-[U-14C]tyrosine was administered (Tables 1 and 2 ; and Whistance et al. 1967). An examination of the possibility that the $D$ isomer was being utilized by the plant formed the first part of our investigations with diluents. The second part of these investigations was concerned with evidence of the nature of the intermediates involved in the conversion of exogenous tyrosine into plastoquinone.

Table 4 shows that, under the experimental conditions used, $100 \mu$ moles of $\mathrm{L}$-tyrosine lowered the incorporation of radioactivity from $\mathrm{L}-\left[\mathrm{U}-{ }^{14} \mathrm{C}\right]$. tyrosine into plastoquinone by $30 \%$, whereas $1000 \mu$ moles prevented completely the incorporation of any radioactivity. On the basis of this result it was decided that diluents would be administered

Table 4. Effect of non-radioactive compounds on the incorporation by maize shoots of radioactivity from ${ }^{14} \mathrm{C}$-labelled tyrosine into plastoquinone and $3 \beta$-hydroxy sterols

Etiolated 7-day-old maize shoots (50/experiment) were excised and exposed with continuous illumination to the appropriate radioactive substrate with and without diluent for $16 \mathrm{hr}$.

Details of incubation

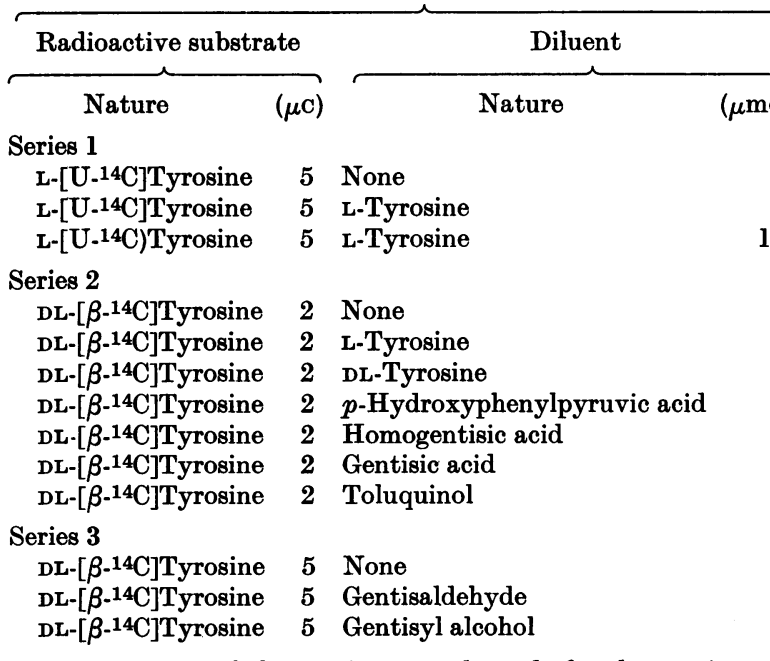

\begin{tabular}{|c|c|c|c|}
\hline \multirow{2}{*}{$\begin{array}{l}\text { Amount of } \\
\text { chlorophyll } \\
\text { at end of } \\
\text { expt. (mg.) }\end{array}$} & \multirow{2}{*}{$\begin{array}{l}{ }^{14} \mathrm{C} \text { radio- } \\
\text { activity } \\
\text { present in } \\
\text { column } \\
\text { fractions } \\
\text { (counts/min.) }\end{array}$} & \multicolumn{2}{|c|}{$\begin{array}{l}\text { Specific radioactivity } \\
\text { (counts/min./mg.) }\end{array}$} \\
\hline & & $\begin{array}{l}\text { Plasto- } \\
\text { quinone* }\end{array}$ & $\begin{array}{c}3 \beta- \\
\text { Hydroxy } \\
\text { sterols }\end{array}$ \\
\hline $5 \cdot 6$ & 8180 & 5060 & 41 \\
\hline $5 \cdot 4$ & 3968 & 3300 & $97(?)$ \\
\hline $5 \cdot 1$ & 0 & 0 & 0 \\
\hline $4 \cdot 8$ & 61540 & 78700 & 1357 \\
\hline $5 \cdot 3$ & 44440 & 53100 & 920 \\
\hline $5 \cdot 3$ & 2992 & 2690 & 154 \\
\hline $5 \cdot 0$ & 6880 & 2052 & 389 \\
\hline 4.9 & 5107 & 1220 & 169 \\
\hline $5 \cdot 2$ & 48710 & 80600 & 1400 \\
\hline $4 \cdot 6$ & 104900 & 111000 & 838 \\
\hline $6 \cdot 0$ & 219400 & 147600 & 1950 \\
\hline $6 \cdot 3$ & 146500 & 124500 & $494(?)$ \\
\hline $5 \cdot 9$ & 212400 & 172500 & 1327 \\
\hline
\end{tabular}

* The amount of plastoquinone at the end of each experiment fell in the range 300-350 $\mu \mathrm{g} . / 50$ shoots, showing that new synthesis of this compound had taken place. 
at the intermediate amount of $500 \mu$ moles. The utilization of exogenous D-tyrosine for plastoquinone biosynthesis was investigated by incubating $\mathrm{DL}-\left[\beta-{ }^{14} \mathrm{C}\right]$ tyrosine with either $500 \mu$ moles of L-tyrosine or $500 \mu$ moles of DL-tyrosine. The results show that L-tyrosine decreased the incorporation of radioactivity into plastoquinone by only $32 \%$, but DL-tyrosine lowered the incorporation by $97 \%$.

Table 4 also records the results of experiments designed to test the efficacy as diluents of various compounds postulated as intermediates in the conversion of DL-tyrosine into plastoquinone. $p$ Hydroxyphenylpyruvic acid and homogentisic acid ( $100 \mu$ moles) were extremely effective diluents, whereas toluquinol, the aglycone of the postulated key intermediate (Whistance \& Threlfall, 1967), showed no dilution effect but rather an enhancement of the incorporation of radioactivity.

Included in Table 4 are the incorporations of radioactivity into the column fractions obtained from column chromatography of the lipid extracts and $3 \beta$-hydroxy sterols. All the dilution effects found for plastoquinone were also observed for these fractions.

To eliminate the possibility that the positive results were due to complete or partial inhibition of the synthesis of the compounds under investigation the amounts of chlorophyll and plastoquinone were measured at the end of each experiment (Table 4). In each case the concentrations were about normal. These findings establish that in all cases normal chloroplast development and new synthesis of plastoquinone had taken place.

The final dilution experiment was concerned with investigating the possibility that 3,4-dihydroxybenzaldehyde was an intermediate in the conversion of shikimic acid into the naphthaquinone nucleus of phylloquinone (Table 5). It was found that, far from diluting out the incorporation of radioactivity from $\left[1,2-{ }^{14} \mathrm{C}_{2}\right]$ shikimic acid, the presence of this compound led to a sixfold increase in the amount of radioactivity incorporated into both phylloquinone and plastoquinone. This we attribute to some form of sparing effect of 3,4-dihydroxybenzaldehyde on $\left[1,2-{ }^{14} \mathrm{C}_{2}\right]$ shikimic acid during its passage up the stem.

On chemical degradation of the plastoquinone isolated in this experiment it was found that $22 \%$ of the radioactivity in the ring was present in one of the ring carbon atoms carrying a methyl group (Table 3). Since we know that the radioactivity in the substrate was equally distributed between C-1 and $\mathrm{C}-2$, this result serves to verify that the synthesis of the plastoquinone nucleus involves symmetrical intermediates, e.g. $p$-hydroxyphenylpyruvate. Further, it shows that C-1 of shikimic acid will give rise to one of the carbon atoms carrying a quinone function.

Incorporation of radioactivity from 3,4-dihydroxy-

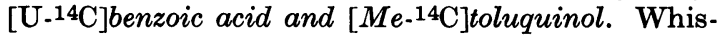
tance \& Threlfall (1967) suggested that homoarbutin, the $\beta$-glucoside of toluquinol, might be a key intermediate in the biosynthesis of plastoquinone and related compounds. However, in dilution experiments the aglycone showed no activity (see above). Since this result could be accounted for by the failure of an effective amount of the diluent either to enter the cell or to become glucosylated, it was decided to prepare and test $\left[\mathrm{Me}-{ }^{14} \mathrm{C}\right]$ toluquinol. Accordingly $\left[\mathrm{Me}-{ }^{14} \mathrm{C}\right]$ toluquinol was synthesized from [Me-14C]toluene (see the Experimental section) and administered ( $5 \mu \mathrm{C}$ supplied) to maize shoots. On analysis, no radioactivity was found in any of the components examined.

The final part of the current investigation with maize shoots was concerned with the possibility that 3,4-dihydroxybenzoic acid might be involved in phylloquinone and ubiquinone biosynthesis. Maize shoots were incubated with $2 \mu \mathrm{C}$ of 3,4-dihydroxy[U-14C]benzoic acid (synthesized enzymically from $p$-hydroxy[U. $\left.{ }^{14} \mathrm{C}\right]$ benzoic acid; see the Experimental section) under our usual experimental conditions. No radioactivity was incorporated into any of the components examined.

Table 5. Effect of 3,4-dihydroxybenzaldehyde on the incorporation of radioactivity from $\left[1,2-14 \mathrm{C}_{2}\right]$ shikimic acid into plastoquinone and phylloquinone

Etiolated 7-day-old maize shoots (100/experiment) were excised and exposed with continuous illumination to $\left[1,2-{ }^{14} \mathrm{C}_{2}\right]$ shikimic acid $(15 \mathrm{mc} / \mathrm{m}$-mole) with and without 3,4-dihydroxybenzaldehyde for $24 \mathrm{hr}$.

Details of incubation

\begin{tabular}{|c|c|c|c|}
\hline \multicolumn{2}{|c|}{ Radioactive substrate } & \multicolumn{2}{|l|}{ Diluent } \\
\hline Nature & $(\mu \mathrm{c})$ & Nature & ( $\mu$ moles $)$ \\
\hline $\begin{array}{l}{\left[1,2-14 \mathrm{C}_{2}\right] \text { Shikimic acid }} \\
{\left[1,2-14 \mathrm{C}_{2}\right] \text { Shikimic acid }}\end{array}$ & $\begin{array}{l}10 \\
10\end{array}$ & $\begin{array}{l}\text { None } \\
\text { 3,4-Dihydroxybenzaldehyde }\end{array}$ & $\overline{500}$ \\
\hline
\end{tabular}

Specific radioactivity (counts/min./mg.) chlorophyll at end of expt. (mg.) $6 \cdot 4$ $6 \cdot 8$ 
Table 6. Incorporation by bean shoots of $\mathrm{L}-\left[\mathrm{U} \cdot{ }^{14} \mathrm{C}\right]$ tyrosine, $\mathrm{DL}-\left[\beta-{ }^{14} \mathrm{C}\right]$ tyrosine and $\mathrm{L}-\left[\mathrm{U}-{ }^{14} \mathrm{C}\right]$ phenylalanine into terpenoid quinones and chromanols

Etiolated 10-day-old bean shoots were excised and exposed with continuous illumination to the appropriate radioactive substrate for $24 \mathrm{hr}$. The characteristics of this experimental system have been shown (D. R. Threlfall, unpublished work) to be similar to those reported for maize shoots (Griffiths et al. 1967).

Specific radioactivity (counts $/ \mathrm{min} . / \mu$ mole)

\begin{tabular}{|c|c|c|c|c|}
\hline Terpenoid & $\begin{array}{l}\text { Amount at end } \\
\text { of expt. } \\
\text { ( } \mu \text { moles) }\end{array}$ & $\begin{array}{c}(5 \cdot 5 \mathrm{mc} / \mathrm{m}-\mathrm{mole}) \\
(120 \text { shoots } \\
\text { incubated with } \\
20 \mu \mathrm{c})\end{array}$ & $\begin{array}{c}(6 \cdot 85 \mathrm{mc} / \mathrm{m}-\mathrm{mole}) \\
(120 \text { shoots } \\
\text { incubated with } \\
10 \mu \mathrm{c})\end{array}$ & $\begin{array}{c}\text { alanine } \\
(6 \cdot 8 \mathrm{mc} / \mathrm{m}-\mathrm{mole}) \\
\text { (120 shootsincubated } \\
\text { with } 20 \mu \mathrm{c})\end{array}$ \\
\hline \multicolumn{5}{|l|}{ Intrachloroplastidic } \\
\hline$\beta$-Carotene & $0 \cdot 138$ & 285 & 325 & $\mathbf{0}$ \\
\hline Phylloquinone & $0 \cdot 222$ & 159 & 329 & 0 \\
\hline Plastoquinone & $0 \cdot 360$ & 13500 & 40100 & $\mathbf{0}$ \\
\hline$\gamma$-Tocopherol & $0 \cdot 168$ & 6760 & 23100 & 0 \\
\hline$\alpha$-Tocopherol & $0 \cdot 149$ & 4705 & Absent & 0 \\
\hline$\alpha$-Tocopherolquinone & $0 \cdot 153$ & 4750 & 13290 & 0 \\
\hline Extrachloroplastidic & & & & \\
\hline $3 \beta$-Hydroxy sterols & $32 \cdot 85$ & 79 & 598 & 75 \\
\hline Ubiquinone-10 & $0 \cdot 315$ & 3850 & 3150 & 2440 \\
\hline $\begin{array}{l}\text { Incorporation of }{ }^{14} \mathrm{C} \text { radioactivity into } \\
\text { column fractions ( } \% \text { of dose given) }\end{array}$ & & $0 \cdot 07^{*}$ & $0 \cdot 38^{*}$ & 0.03 \\
\hline
\end{tabular}

* Distribution of radioactivity between column fractions similar to those reported for parallel experiments with maize (Table 1).

\section{Experiments with beans}

Incorporation of $\mathrm{L}-\left[\mathrm{U}-{ }^{14} \mathrm{C}\right]$ tyrosine, $\mathrm{DL}-\left[\beta-{ }^{14} \mathrm{C}\right]$ tyrosine and $\mathrm{L}-\left[\mathrm{U}-{ }^{14} \mathrm{C}\right]$ phenylalanine. Neish (1961) reported that all grasses so far examined show both phenylalanine deaminase and tyrase activity; legumes, on the other hand, though having phenylalanine deaminase activity, have only poor tyrase activity. If this is the case, then in beans phenylalanine should be effectively incorporated into ubiquinone and tyrosine should not. Etiolated bean shoots and leaves were incubated with $\mathrm{L}-\left[\mathrm{U}-{ }^{14} \mathrm{C}\right]$ tyrosine, DL- $\left[\beta-{ }^{14} \mathrm{C}\right]$ tyrosine or $\mathrm{L}-\left[\mathrm{U}-{ }^{14} \mathrm{C}\right]$ phenylalanine for $24 \mathrm{hr}$. in the light. Table 6 summarizes the results obtained.

In agreement with the results obtained with maize shoots it was found that radioactivity from DL- $\left[\beta-{ }^{14} \mathrm{C}\right]$ tyrosine was more effectively incorporated than radioactivity from $\mathrm{L}-\left[\mathrm{U} \cdot{ }^{14} \mathrm{C}\right]$ tyrosine.

From the comparative approach employed in the maize experiments it is apparent that: $(a)$ radioactivity from $\mathrm{DL}-\left[\beta-{ }^{14} \mathrm{C}\right]$ tyrosine was specifically incorporated into plastoquinone, $\gamma$-tocopherol and $\alpha$-tocopherolquinone, and generally incorporated into $\beta$-carotene, phylloquinone, $3 \beta$-hydroxy sterols and ubiquinone; $(b)$ radioactivity from $L-[U-14 C]$ tyrosine was specifically incorporated into all quinones and chromanols except phylloquinone; (c) radioactivity from $\mathrm{L}$-[U.14C]phenylalanine was specifically incorporated only into ubiquinone. Chemical degradations of representative compounds labelled from the two $\left[{ }^{14} \mathrm{C}\right]$ tyrosine substrates (Table 7) gave results similar to those obtained in the experiments with maize shoots.

The result showing the incorporation of radioactivity into ubiquinone was somewhat unexpected. However, the finding that radioactivity from L-[U-14C]phenylalanine was not incorporated into any of the intrachloroplastidic components examined indicates that beans do not possess a phenylalanine hydroxylase.

\section{Experiments with ivy}

Results so far described have shown that, in the biosynthesis of plastoquinone, tocopherols and tocopherolquinones, the nucleus and one nuclear methyl group can be formed from a $\mathrm{C}_{6}-\mathrm{C}_{1}$ unit, derived most probably from $p$-hydroxyphenylpyruvic acid. It was therefore decided to determine whether $\delta$-tocopherol (a monomethyl chromanol) was labelled from $\mathrm{DL} \cdot\left[\beta \cdot{ }^{14} \mathrm{C}\right]$ tyrosine, since this has a direct bearing on the orientation of the $\beta$-carbon atom of tyrosine in the assembled molecules. Ivy leaves were chosen as experimental tissues because they are reported to contain $\delta$-tocopherol (Booth, 1963).

Analysis of ivy leaves. Before radiochemical studies the nature and identity of the quinones and 
Table 7. Intramolecular distribution of radioactivity in quinones and chromanols isolated from bean and ivy

Chemical degradation carried out by the routine procedures described in Table 4 and the Experimental section.

\begin{tabular}{|c|c|c|c|c|}
\hline \multirow[b]{2}{*}{ Plant } & \multirow[b]{2}{*}{ Substrate } & \multirow[b]{2}{*}{ Sample } & \multicolumn{2}{|c|}{$\%$ of total radioactivity in molecule } \\
\hline & & & $\begin{array}{l}\text { Polyprenyl } \\
\text { unit }\end{array}$ & $\begin{array}{l}\text { Nuclear methyl } \\
\text { groups }\end{array}$ \\
\hline Bean & DL- $\left[\beta-{ }^{-14} \mathrm{C}\right]$ Tyrosine & $\begin{array}{l}\text { Plastoquinone } \\
\gamma \text {-Tocopherol }\end{array}$ & $\begin{array}{l}1 \\
<4 \text { (by diff.) }\end{array}$ & $\begin{array}{l}98 \\
96\end{array}$ \\
\hline & L-[U.14C]Tyrosine & $\begin{array}{l}\text { Plastoquinone } \\
\text { Ubiquinone-10 }\end{array}$ & $\begin{array}{l}2 \text { (calc.) } \\
13\end{array}$ & $\begin{array}{c}14^{*} \\
87 \% \text { (by diff.) } \\
\text { in nucleus }\end{array}$ \\
\hline Ivy & DL- $\left[\beta-{ }^{14} \mathrm{C}\right]$ Tyrosine & $\begin{array}{l}\text { Plastoquinone } \\
\gamma \text {-Tocopherol } \\
\alpha \text {-Tocopherol }\end{array}$ & $\begin{array}{l}<4 \text { (by diff.) } \\
<6 \text { (by diff.) } \\
<3 \text { (by diff.) }\end{array}$ & $\begin{array}{l}96 \\
94 \\
97\end{array}$ \\
\hline & $\mathrm{L}-\left[M e^{-14} \mathrm{C}\right]$ Methionine & $\begin{array}{l}\text { Plastoquinone } \\
\gamma \text {-Tocopherol } \\
\alpha \text {-Tocopherol } \\
\text { Ubiquinone-10† }\end{array}$ & $\begin{array}{l}<2 \text { (by diff.) } \\
<\overline{6} \text { (by diff.) }\end{array}$ & $\begin{array}{c}98 \\
102 \\
94 \\
28 \text { (by diff.) }\end{array}$ \\
\hline
\end{tabular}

* $28 \%$ of the total radioactivity in the molecule was in the nuclear carbon atom carrying methyl groups.

$\dagger$ Zeisel degradation established that $72 \%$ of the radioactivity in the molecule was in the methoxyl groups.

chromanols occurring in ivy leaves were determined. A mass (110g., wet wt.) of ivy leaves collected in November 1966 was extracted to give $2.08 \mathrm{~g}$. of lipid extract. A $1 \mathrm{~g}$. sample was taken and chromatographed on a column of acid-washed alumina (Table 8). As expected, phylloquinone, plastoquinone, $\gamma$-tocopherol, $\alpha$-tocopherol, $\alpha$-tocopherolquinone and ubiquinone-10 were all found to be present. Ubiquinone-10 is the homologue normally found in higher plants.

The $3 \%-\mathrm{E} / \mathrm{P}$ and $12 \%-\mathrm{E} / \mathrm{P}$ fractions were found to contain compounds having spectra qualitatively identical with those of plastoquinone. In the $12 \%-\mathrm{E} / \mathrm{P}$ fraction the spectrum was due to the plastoquinone $\mathrm{C}$ complex (Griffiths, Wallwork \& Pennock, 1966; Threlfall \& Griffiths, 1967; Das, Lounasmaa, Tendile \& Lederer, 1967) and in the $3 \%-\mathrm{E} / \mathrm{P}$ fraction to the plastoquinone $\mathrm{B}$ complex (Griffiths, 1967).

Previous experiments had established that under our chromatographic conditions $\delta$-tocopherol is eluted by $8 \% \mathrm{E} / \mathrm{P}$. Accordingly the $8 \%-\mathrm{E} / \mathrm{P}$ fraction from ivy was chromatographed quantitatively on thin layers developed with ethyl acetate-benzene $(3: 22, \mathrm{v} / \mathrm{v})$. A u.v.-absorbing band $\left(R_{F} 0 \cdot 46\right)$ was recovered and shown to have a u.v. spectrum qualitatively identical with that of $\delta$-tocopherol (Fig. 1), i.e. $\lambda_{\max .} 295 \mathrm{~m} \mu$ in cyclohexane. The sample, when chromatographed in all the thin-layer systems listed in the Experimental section for the purification of $\delta$-tocopherol, had the same $R_{F}$ as authentic $\delta$-tocopherol. Finally a sample was oxidized with gold chloride (Dilley \& Crane, 1963)

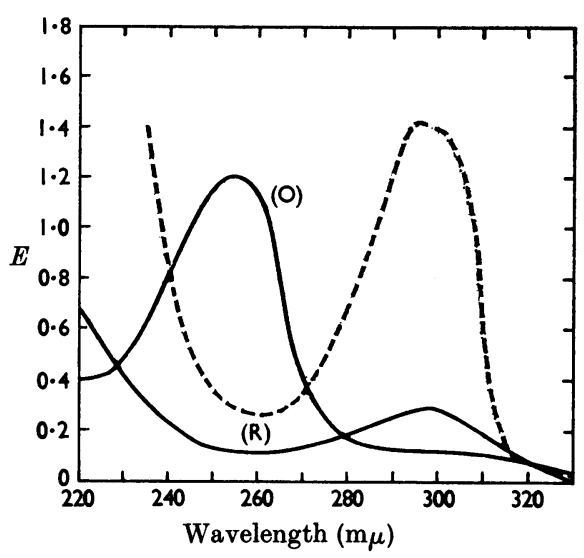

Fig. 1. Ultraviolet spectra of $\delta$-tocopherol and $\delta$-tocopherolquinone. -- - , $\delta$-Tocopherol (in cyclohexane) isolated from ivy leaves.,$- \delta$-Tocopherolquinone (in ethanol) formed by gold chloride oxidation of $\delta$-tocopherol $(0)$ and after treatment with $\mathrm{NaBH}_{4}(\mathrm{R})$.

and, after purification on thin layers developed with ethyl acetate-benzene $(3: 22, \mathrm{v} / \mathrm{v})\left(R_{F} 0 \cdot 2\right)$, the u.v. spectra (oxidized and reduced) of the purified product were determined (Fig. 1). They were found to be identical with those obtained on oxidation of authentic $\delta$-tocopherol.

Incorporation of $\cdot \mathrm{L}-\left[\mathrm{Me} \cdot{ }^{14} \mathrm{C}\right]$ methionine and $\mathrm{DL}$ $\left[\beta-{ }^{14} \mathrm{C}\right]$ tyrosine. To provide an effective control for the incorporation of radioactivity from $D L-\left[\beta-{ }^{14} \mathrm{C}\right]$ - 
Table 8. Incorporation by ivy leaves of $\mathrm{L}-\left[M e-{ }^{14} \mathrm{C}\right]$ methionine and $\mathrm{DL}-\left[\beta-{ }^{14} \mathrm{C}\right]$ tyrosine into terpenoid quinones and chromanols

Ivy leaves (60g. fresh wt./experiment) were coated with an aqueous solution of the appropriate radioactive substrate and incubated at room temperature with continuous illumination. Approx. lg. of lipid was obtained in each experiment. N.D., Not determined.

\begin{tabular}{|c|c|c|c|c|c|c|c|}
\hline \multirow[b]{2}{*}{$\begin{array}{l}\text { Fraction } \\
(\% \mathrm{E} / \mathrm{P})\end{array}$} & \multirow[b]{2}{*}{$\begin{array}{l}\text { Wt.* } \\
\text { (mg.) }\end{array}$} & \multicolumn{2}{|c|}{${ }^{14} \mathrm{C}$ radioactivity (counts/min.) } & & & \multicolumn{2}{|c|}{$\begin{array}{l}\text { Specific radioactivity } \\
\text { (counts } / \mathrm{min} . / \mu \text { mole) }\end{array}$} \\
\hline & & $\begin{array}{c}\mathrm{L}-\left[M e-{ }^{14} \mathrm{C}\right] \text { Methionine } \\
(56 \cdot 8 \mathrm{mc} / \mathrm{m} \text {-mole }) \\
(60 \mathrm{~g} . \text { of leaves } \\
\text { incubated with } 25 \mu \mathrm{c})\end{array}$ & $\begin{array}{c}\text { DL- }[\beta-14 \mathrm{C}] \text { Tyrosine } \\
(6 \cdot 85 \mathrm{mc} / \mathrm{m}-\mathrm{mole}) \\
(60 \mathrm{~g} . \text { of leaves } \\
\text { incubated with } 10 \mu \mathrm{c})\end{array}$ & Terpenoids* present & $\begin{array}{l}\text { Amount* } \\
(\mu \text { moles })\end{array}$ & $\begin{array}{l}\mathrm{L}-\left[M e-{ }^{14} \mathrm{C}\right]- \\
\text { Methionine }\end{array}$ & $\begin{array}{c}\text { DL- }\left[\beta-{ }^{-14} \mathrm{C}\right]- \\
\text { Tyrosine }\end{array}$ \\
\hline $0 \cdot 25$ & $87 \cdot 1$ & 1905 & 3385 & $\begin{array}{l}\text { Squalene } \\
\beta \text {-Carotene } \\
\text { Phylloquinone }\end{array}$ & $\begin{array}{l}\text { N.D. } \\
\text { N.D. } \\
0 \cdot 22\end{array}$ & $\begin{array}{r}0 \\
0 \\
75\end{array}$ & $\begin{array}{l}0 \\
0 \\
0\end{array}$ \\
\hline 1 & $32 \cdot 8$ & 18600 & 18500 & Plastoquinone & $13 \cdot 37$ & 738 & 1750 \\
\hline 3 & $36 \cdot 8$ & 8850 & 3660 & $\begin{array}{l}\alpha \text {-Tocopherol } \\
\text { Plastoquinone B }\end{array}$ & $\begin{array}{r}26 \cdot 90 \\
5 \cdot 65\end{array}$ & $\begin{array}{r}418 \\
\text { Trace }\end{array}$ & $\begin{array}{c}105 \\
\text { Trace }\end{array}$ \\
\hline 5 & $70 \cdot 7$ & 14150 & 8140 & $\begin{array}{l}\gamma \text {-Tocopherol } \\
\text { Ubiquinone-10 }\end{array}$ & $\begin{array}{l}2 \cdot 31 \\
0 \cdot 81\end{array}$ & $\begin{array}{l}1668 \\
2255\end{array}$ & $\begin{array}{r}2365 \\
24\end{array}$ \\
\hline 8 & $47 \cdot 9$ & 7040 & $2845 \dagger$ & $\delta$-Tocopherol & 0.50 & 0 & 176 \\
\hline 12 & $43 \cdot 4$ & 6050 & 0 & $\begin{array}{l}3 \beta \text {-Hydroxy sterols } \\
\text { Plastoquinone } \mathrm{C}\end{array}$ & $\begin{array}{r}21 \cdot 60 \\
2 \cdot 96\end{array}$ & $\begin{array}{c}280 \\
\text { Trace }\end{array}$ & $\begin{array}{c}1 \\
\text { Trace }\end{array}$ \\
\hline 20 & $33 \cdot 1$ & 6740 & 1680 & $\alpha$-Tocopherolquinone & 0.54 & N.D. & N.D. \\
\hline ncorpor & 10 & $0 \cdot 11$ & $0 \cdot 17$ & & & & \\
\hline
\end{tabular}

column fractions $(\%)$

* Taken from a preliminary analysis. The leaves in the radiochemical experiments were similar.

$\dagger$ Some $\gamma$-tocopherol present in this fraction.

tyrosine into $\delta$-tocopherol, the incorporation of radioactivity from $\mathrm{L}-\left[\mathrm{Me}-{ }^{14} \mathrm{C}\right]$ methionine into this compound was also examined.

Ivy leaves (60g. fresh wt./experiment), were coated with an aqueous solution of the appropriate radiochemical, and then spread out on a glass plate and illuminated for $6 \mathrm{hr}$.

On administration of $\mathrm{L}$-[ $\left.\mathrm{Me}-{ }^{14} \mathrm{C}\right]$ methionine, plastoquinone, $\gamma$-tocopherol, $\alpha$-tocopherol, phylloquinone, ubiquinone-10 and $3 \beta$-hydroxy sterols were all significantly labelled (Table 8). Chemical degradations established that in the first three compounds all the radioactivity was in nuclear methyl groups (Table 7); the radioactivity in ubiquinone was shown to be divided between the nuclear methyl (28\%) and methoxyl (72\%) groups (Table 7). $\delta$-Tocopherol was completely nonradioactive, showing that its nuclear methyl group was not derived from methionine.

When $\mathrm{DL}-\left[\beta-{ }^{14} \mathrm{C}\right]$ tyrosine was administered, radioactivity was specifically incorporated into the nuclear methyl groups of plastoquinone, $\gamma$-tocopherol and $\alpha$-tocopherol (Tables 7 and 8). $\delta$-Tocopherol was only poorly labelled from this substrate.
Nevertheless there can be little doubt, especially when it is remembered that radioactivity from $\mathrm{L}-\left[\mathrm{Me}-{ }^{14} \mathrm{C}\right]$ methionine was not incorporated into this molecule, that the radioactivity in $\delta$-tocopherol was associated entirely with the 8-methyl group.

The plastoquinone $\mathbf{B}$ and plastoquinone $\mathbf{C}$ complexes in both experiments were found to contain very little radioactivity, suggesting that they are products of the metabolism of plastoquinone.

\section{Experiments with Euglena}

To complete these studies we examined the utilization by Euglena gracilis of exogenous tyrosine for quinone and chromanol synthesis.

Incorporation of $\mathrm{L}-\left[\mathrm{U}-{ }^{14} \mathrm{C}\right]$ tyrosine and $\mathrm{DL}-\left[\beta-{ }^{14} \mathrm{C}\right]$. tyrosine. Cells of Euglena gracilis strain $\mathrm{Z}$ were suspended in buffer and incubated for $6 \mathrm{hr}$. in the light with either $\mathrm{L}-\left[\mathrm{U}-{ }^{14} \mathrm{C}\right]$ tyrosine or $\mathrm{DL}-\left[\beta-{ }^{14} \mathrm{C}\right]$ tyrosine.

When L-[U-14C]tyrosine was administered radioactivity was found in all components examined (Table 9). The specific radioactivity of $\beta$-carotene was found to be about the same as or higher than 


\section{Table 9. Incorporation by Euglena of $\mathrm{L}-\left[\mathrm{U}-{ }^{14} \mathrm{C}\right]$ tyrosine and $\mathrm{DL}-[\beta-14 \mathrm{C}]$ tyrosine into terpenoid quinones and chromanols}

Light-grown 4-day-old cells of Euglena gracilis, from 1l. of culture medium, were suspended in $100 \mathrm{ml}$. of $0.04 \mathrm{M}-$ phosphate buffer, $\mathrm{pH} \mathrm{6 \cdot 7,} \mathrm{containing} \mathrm{the} \mathrm{radioactive} \mathrm{substrate} \mathrm{and} \mathrm{exposed} \mathrm{to} \mathrm{light} \mathrm{for} 6 \mathrm{hr}$. The nature of the quinones and chromanols occurring in this organism has been reported by Threlfall \& Goodwin (1967). N.D., Not determined.

\begin{tabular}{|c|c|c|c|}
\hline Terpenoid & $\begin{array}{c}\text { Amount* } \\
(\mu \text { mole })\end{array}$ & $\begin{array}{c}\text { L-[U.14C]Tyrosine } \\
(5 \cdot 5 \mathrm{mc} / \mathrm{m}-\mathrm{mole}) \\
(10 \mu \mathrm{C} \text { used })\end{array}$ & $\begin{array}{c}\text { DL- }\left[\beta-{ }^{14} \mathrm{C}\right] \text { Tyrosine } \\
(6 \cdot 85 \mathrm{mc} / \mathrm{m}-\mathrm{mole}) \\
(10 \mu \mathrm{c} \text { used })\end{array}$ \\
\hline \multicolumn{4}{|l|}{ Intrachloroplastidic } \\
\hline$\beta$-Carotene & 0.51 & 8260 & 19240 \\
\hline Plastoquinone & $0 \cdot 87$ & 5430 & $24825 \dagger$ \\
\hline$\alpha$-Tocopherol & 0.64 & 9340 & N.D. \\
\hline$\alpha$-Tocopherolquinone & $0 \cdot 06$ & 9420 & N.D. \\
\hline \multicolumn{4}{|l|}{ Extrachloroplastidic } \\
\hline Ubiquinone-9 & 0.07 & 5430 & N.D. \\
\hline
\end{tabular}

* Values from the L-[U-14C]tyrosine experiment. In this analysis $\gamma$-tocopherol, a compound which had not previously been reported as occurring in Euglena, was shown to be a normal lipid constituent.

$\dagger$ Ozonolytic degradation showed that $52 \%$ of the radioactivity was in the nonaprenyl side chain.

those of plastoquinone, $\alpha$-tocopherol, $\alpha$-tocopherolquinone and ubiquinone, suggesting that a considerable amount of the radioactivity in these molecules was probably in the side chains. In the $\mathrm{DL}-\left[\beta-{ }^{14} \mathrm{C}\right]$ tyrosine experiment only plastoquinone and $\beta$-carotene were examined (Table 9); again considerable radioactivity was present in the $\beta$-carotene. Chemical degradation of the plastoquinone sample from this experiment established that $52 \%$ of the radioactivity in the molecule was in the side chain (Table 7). These results show that Euglena can carry out extensive degradation of the tyrosine molecule to give metabolites capable of entering the biosynthetic sequences of isoprenoid formation.

\section{DISCUSSION}

By the use of specifically labelled aromatic amino acids it has been unequivocally established that in maize shoots the nuclear carbon atoms and $\beta$-carbon atoms of either exogenous tyrosine or phenylalanine are used for the synthesis of the nuclei and nuclear methyl groups (one in each case) respectively of plastoquinone, $\gamma$-tocopherol and $\alpha$-tocopherolquinone (Tables 2 and 3 ). In this process the $\alpha$-carbon atoms and carboxyl carbon atoms are lost. The finding that on chemical degradation of plastoquinone and $\gamma$-tocopherol labelled from L-[U.14C]tyrosine one-seventh of the radioactivity in the molecules is in the nuclear methyl groups demonstrates that a $\mathrm{C}_{6}-\mathrm{C}_{1}$ unit formed directly from the amino acids is used in the synthesis. The possibility that this unit could be derived from any of the many $\mathrm{C}_{6}-\mathrm{C}_{1}$ phenolic acids formed from the deamination products of tyrosine ( $p$-coumaric acid) and phenylalanine (cinnamic acid), for example gentisic acid formed by the sequence cinnamic acid $\rightarrow 0$-coumaric acid $\rightarrow$ gentisic acid, is eliminated by the negative result obtained on administering [side-chain-3-14 $\mathrm{C}$ ]cinnamic acid (Table 2). In ubiquinone the aromatic carbon atoms of the amino acids are used in the synthesis of the $p$-benzoquinone nucleus (Table 3 ), the nuclear methyl group coming from methionine (Threlfall et al. 1968).

Experiments with bean and ivy leaves, though less conclusive than those with maize shoots, established that in these tissues also the aromatic carbon atoms and $\beta$-carbon atom of tyrosine are used for the synthesis of plastoquinone, $\delta$-tocopherol (ivy), $\gamma$-tocopherol, $\alpha$-tocopherol and $\alpha$-tocopherolquinone (bean) (Tables 6, 7 and 8). Only the nuclear carbon atoms of tyrosine are used for ubiquinone synthesis (Tables 6 and 8). Exogenous phenylalanine was used by beans only for ubiquinone synthesis (Table 6); the utilization of this amino acid by ivy leaves was not investigated. In ivy tissues radioactivity from $\mathrm{L}-\left[\mathrm{Me}^{\left.-{ }^{14} \mathrm{C}\right] \text { methionine }}\right.$ was incorporated into all the quinones and chromanols examined except $\delta$-tocopherol (Table 8); chemical degradations of selected samples estab. lished that, as in previous experiments with maize shoots (Threlfall et al. 1968), radioactivity was present only in nuclear methyl and methoxyl (ubiquinone) groups (Table 7). The result for $\delta$-tocopherol was complementary to the result obtained with DL-[ $\left.\beta-{ }^{14} \mathrm{C}\right]$ tyrosine and serves to establish that the 8-methyl group is formed from the $\beta$-carbon atom of tyrosine. 
Experiments with the alga Euglena gracilis yielded no useful information on the biosynthesis of the compounds under investigation because extensive degradation of the radioactive substrates occurred.

On the basis of the observed incorporation of radioactivity from $\mathrm{DL}-\left[\beta-{ }^{14} \mathrm{C}\right]$ tyrosine into $\delta$-tocopherol and the failure to find in Nature monomethyl tocols or tocotrienols other than the 8-methyl forms, we suggest that, in $\gamma$-tocopherol, $\alpha$-tocopherol, $\alpha$-tocopherolquinone, plastoquinone and all related compounds, the $\beta$-carbon atom of tyrosine gives rise to the methyl groups meta to the polyprenyl side chains. If $\delta$-tocopherol, $\gamma$-tocopherol, $\alpha$-tocopherol and $\alpha$-tocopherolquinone are biosynthetically related then this must obviously be the case.

During these experiments it was repeatedly observed that the highest incorporation of radioactivity was obtained when $\mathrm{DL}-\left[\beta-{ }^{14} \mathrm{C}\right]$ tyrosine was administered, the incorporation of radioactivity from this substrate being some six (beans) to 20 (maize) times as high as when L-[U-14C]tyrosine was given under similar conditions (Tables 2 and 6; and Whistance et al. 1967). This led us to consider the possibility that the $\mathrm{D}$-isomer of this amino acid was being metabolized in some manner that made it more readily available than the $\mathrm{L}$-isomer for the synthesis of plastoquinone and related compounds. These comments also apply to the catabolic processes, which we believe can take place via $p$. hydroxyphenylpyruvate (see below), leading to the incorporation of radioactivity into the $3 \beta$-hydroxy sterols and polyprenyl portions of the molecules under investigation (Tables 2, 4 and 6). An appropriate dilution experiment provided convincing evidence that in maize shoots the $D$-isomer of tyrosine is utilized more readily than the L-isomer for plastoquinone synthesis (Table 4). The situation is obviously difficult to interpret at present. However, if we accept that to be used for plastoquinone synthesis both forms must reach the chloroplast and give rise to $p$-hydroxyphenylpyruvic acid (see below), then it is tempting to suggest that any D-tyrosine entering the plant can be metabolized only in the chloroplast, whereas L-tyrosine can of course be readily utilized throughout the plant. This means that more exogenous $D$-tyrosine than L-tyrosine will reach the chloroplast and undergo transamination to form the $\alpha$-oxo acid required for plastoquinone biosynthesis, and this in turn will lead to a higher incorporation of radioactivity from the ${ }^{14} \mathrm{C}$-labelled $\mathrm{D}$-isomer. With $\mathrm{DL}-\left[{ }^{14} \mathrm{C}\right]$ phenylalanine substrates no such preferential utilization of the $\mathrm{D}$-isomer is observed (Table 2, and Whistance et al. 1967). This is because the $\mathrm{D}$-isomer can be utilized only for plastoquinone, tocopherol and ubiquinone synthesis by way of the L-isomer (Scheme 3), so at best the incorporation of radio. activity can only be the same as the incorporation obtained with L-[U-14C]phenylalanine.

From a consideration of the above information and the results of previous experiments with $3(R S)-\left[2-{ }^{14} \mathrm{C},(4 R)-4-{ }^{3} \mathrm{H}_{1}\right]$ mevalonic acid (Dada et al. 1968), $\mathrm{L}-\left[M e-{ }^{14} \mathrm{C},{ }^{3} \mathrm{H}\right]$ methionine (Threlfall et al. 1968), [G-14 $\mathrm{C}]$ shikimic acid and $p$-hydroxy[U-14 $\mathrm{C}]$ benzoic acid (Whistance et al. 1967) an outline of the possible relationships of the various quinone and chromanol nuclei to some of the biosynthetic intermediates and catabolites associated with the metabolism of phenylalanine and tyrosine (Scheme 3) can be suggested. In Scheme $3 p$-hydroxyphenylpyruvic acid is shown as the intermediate required for the synthesis of plastoquinone and related compounds; experimental support for this proposal comes from the finding that the addition of $p$-hydroxyphenylpyruvate to maize shoots metabolizing $\mathrm{DL}-\left[\beta-{ }^{14} \mathrm{C}\right]$ tyrosine lowers the incorporation of radioactivity into plastoquinone (Table 4). To account for the incorporation by maize shoots of radioactivity from $\left[{ }^{14} \mathrm{C}\right]$ phenylalanine into plastoquinone and related compounds, it is proposed that these tissues contain the enzyme phenylalanine hydroxylase; this enzyme has been shown to be present in Salvia splendens, Triticum vulgare, Fagopyrum tartaricum (McCalla \& Neish, 1959; Gamborg \& Neish, 1959) and spinach (Nair \& Vining, 1965). However, in the light of our results it would appear to be absent from bean tissues (Table 6).

Accepting that the shikimic acid pathway of aromatic acid biosynthesis is operative both inside and outside the chloroplast, we suggest that in the higher-plant tissues used the sequences shikimic acid $\rightarrow$ phylloquinone and $p$-hydroxyphenylpyruvic acid $\rightarrow$ plastoquinone and related compounds (or at least certain key reactions associated with these sequences) occur only in the chloroplast. We further suggest that the sequence cinnamic acid $\rightarrow p$. hydroxybenzoic acid $\rightarrow$ ubiquinone takes place outside the chloroplast.

The present state of knowledge of the biosynthesis of ubiquinone by plants, animals and microorganisms has been discussed by Whistance et al. (1967). It is worth recapitulating that in plants nothing is known of the pathway by which the nucleus of $p$-hydroxybenzoic acid gives rise to the $p$-benzoquinone nucleus of ubiquinone, except that the carboxyl group of $p$-hydroxybenzoic acid is lost and that 2-polyprenylphenols and 2-polyprenyl6-methoxyphenols are not apparently involved. In the present investigation it was shown that radioactivity from 3,4-dihydroxy[U-14C]benzoic acid, which could be visualized as a possible intermediate in the conversion of $p$-hydroxybenzoic acid into ubiquinone, was not incorporated into ubiquinone. Sharma \& Ramasarma (1967) reported the isolation of a compound from Tecoma stans and Phaseolus 


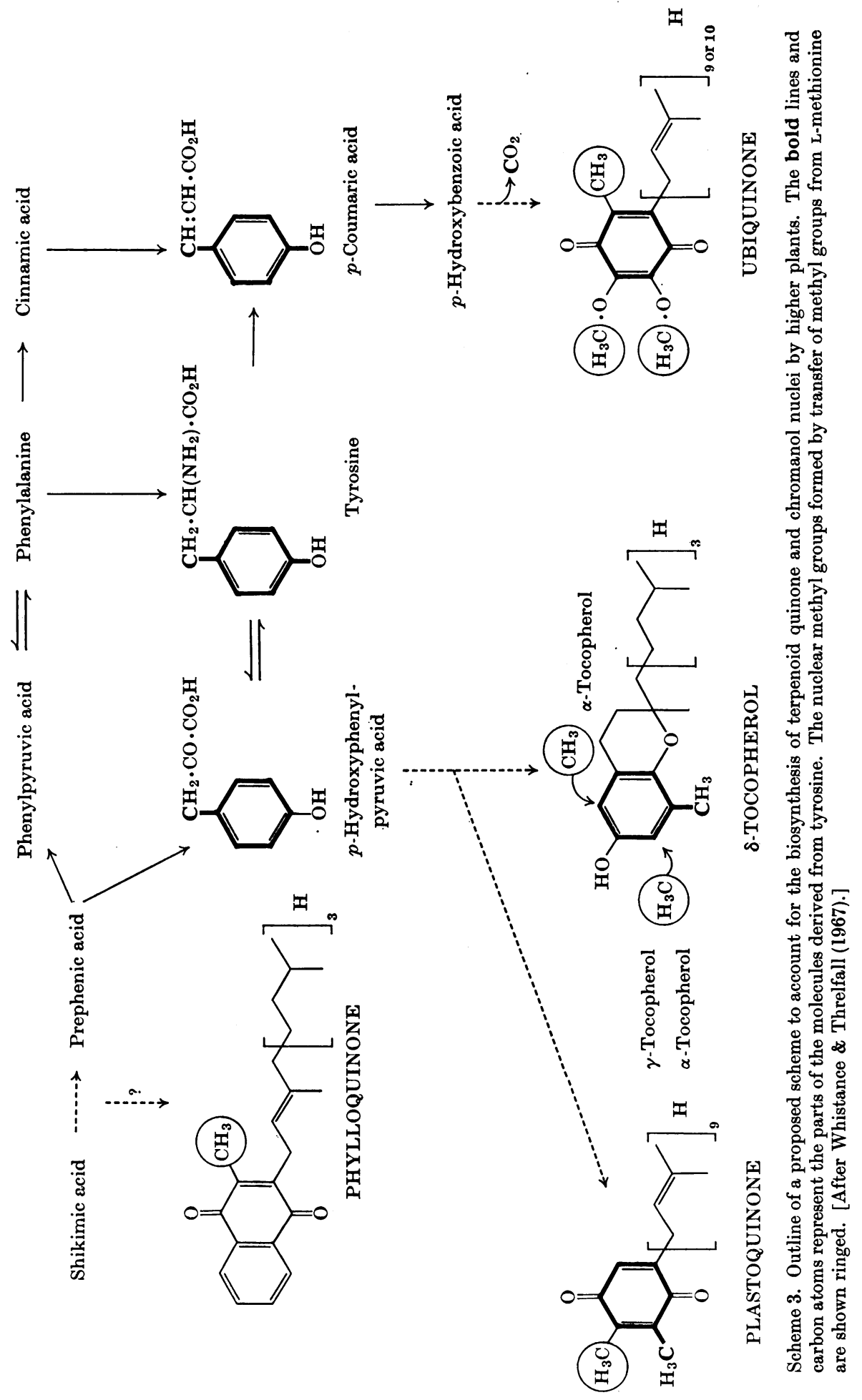


radiatus that they suggested might be a possible ubiquinone precursor. However, from a consideration of the properties reported there is little doubt that it is 'compound 310' ( $N$-phenyl-2-naphthylamine) (Brown, 1967) present as a contaminant in the solvents used.

In Scheme 3 the naphthaquinone nucleus of phylloquinone is shown as arising early in the shikimic acid pathway. This is based solely on the experimental observation that of all radioactive substrates so far tested only with [G-14C]shikimic acid was radioactivity incorporated into the nucleus (Whistance et al. 1967). Dilution and radiochemical experiments showed that 3,4-dihydroxybenzaldehyde (Table 5), a compound once thought to be implicated in the biosynthesis of the menaquinone nucleus by Escherichia coli (Cox \& Gibson 1964), and 3,4-dihydroxybenzoic acid are not involved in the biosynthesis of phylloquinone. These results are not unexpected in view of the demonstration that these two compounds are not involved in menaquinone biosynthesis in Escherichia coli (Campbell, Cosica, Kelsey \& Bentley, 1967).

The route by which $p$-hydroxyphenylpyruvic acid is incorporated into plastoquinone, tocopherols and $\alpha$-tocopherolquinones has still to be determined. However, from the orientations of the $\beta$-carbon atom and the oxygen function in the parent molecule (para) and products (meta) (although ortho is possible it appears unlikely), it is necessary to visualize an intramolecular shift involving one or other of these groups. On the basis of reports of the isolation of homogentisic acid from Lupinus albus (Bertel, 1903) and homoarbutin from Pyrola rotundiflora (Inoue, Arai \& Takano, 1958), and the occurrence in plant tissues of the various tocotrienols $(\delta$-, $\gamma-, \beta$ - and $\alpha-)$ and their corresponding tocopherols (Pennock, Hemming \& Kerr, 1964), Whistance \& Threlfall (1967) were led to propose that the pathway outlined in Scheme 4 could account for the biosynthesis of plastoquinones and tocopherols in higher plants.

The first step(s) from $p$-hydroxyphenylpyruvic acid to homogentisic acid would proceed in a similar manner to that found in animal tissues, i.e. hydroxylation of the aromatic ring, shift of the side chain and the formation of carbon dioxide (see, e.g., Meister, $1965)$. Homogentisic acid, possibly as its $\beta$-glucoside, would then be converted into the key intermediate, homoarbutin. Nonaprenylation, methylation and deglycosylation (not necessarily in this sequence) of homoarbutin would give plastoquinone. Tetraprenylation, cyclization and deglycosylation would give $\delta$-tocotrienol, a compound that can be regarded as the parent member of both the tocotrienol and tocopherol series. $\delta$-Tocotrienol could then by suitable hydrogenation and methylation reactions form all members of the two series. These

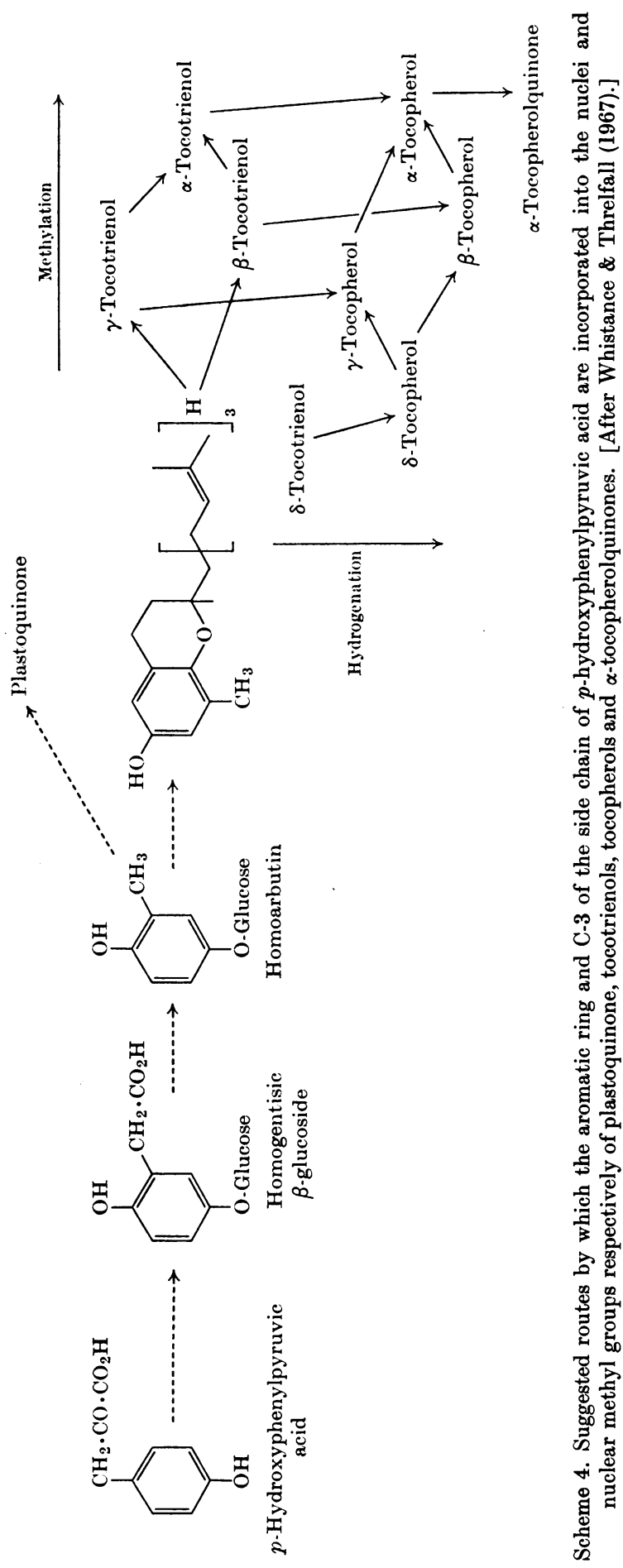




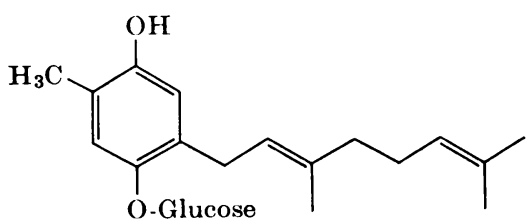

(I) Pyrolatin

suggestions were supported by the isolation from Pyrola japonica of pyrolatin (I) (Inoue \& Takano, 1958), since this compound with its diprenyl side chain has obvious structural affinities with the compounds under consideration. It is noteworthy that the results obtained for the chemical degradation of plastoquinone labelled from $\left[1,2-{ }^{14} \mathrm{C}_{2}\right]$ shikimic acid are consistent with the above proposals (Table 7).

Dilution studies have provided convincing evidence that in maize shoots homogentisic acid is involved in the biosynthesis of plastoquinone (Table 5). Toluquinol, the aglycone of homoarbutin, and a range of compounds that could be visualized as intermediates in the conversion of homogentisic into toluquinol, i.e. gentisic acid, gentisaldehyde and gentisyl alcohol, failed to show any dilution effects (Table 4). Further, radioactivity from [Me- $\left.{ }^{14} \mathrm{C}\right]$ toluquinol was not incorporated into any compound examined. These experiments appear to exclude homoarbutin as the key intermediate; however, the argument can be advanced that exogenous toluquinol may not be $\beta$-glucosylated and would thus remain metabolically inert.

In Scheme 4, members of the tocotrienol and tocopherol series are shown as constituting a 'metabolic grid' (Bu'Lock, 1965), so that the route from $\delta$-tocotrienol to $\alpha$-tocopherol could be by any of several permutations. Pennock et al. (1964) suggested a possible route for the final steps of $\alpha$-tocopherol synthesis that involves methylation of $\delta$-tocotrienol to $\beta$-tocotrienol or $\gamma$-tocotrienol, further methylation to $\alpha$-tocotrienol, followed by reduction to $\alpha$-tocopherol. However, an investigation of the incorporation by Hevea latex of radioactivity from $\mathrm{L}-\left[\mathrm{Me}-{ }^{14} \mathrm{C}\right]$ methionine into $\gamma$-tocotrienol, $\beta$-tocotrienol, $\alpha$-tocotrienol and $\alpha$-tocopherol failed to provide any convincing evidence for these proposals (Whittle, Audley \& Pennock, 1967).

In our experience $\gamma$-tocopherol always has a higher specific radioactivity than $\alpha$-tocopherol (and $\alpha$-tocopherolquinone), which suggests a possible precursor-product relationship (Tables 2, 7 and 8; also Whistance et al. 1967; Threlfall et al. 1968). $\delta$-Tocopherol produced in the ivy experiment had a lower specific radioactivity than $\gamma$-tocopherol, but a higher one than $\alpha$-tocopherol, which suggests that possibly some of the compounds are produced as a consequence of side reactions and are not intermediates at all.

Again, in considering the biosynthesis of tocotrienols and tocopherols, it must be recalled that alternative biosynthetic sequences can be invoked. For example, the nucleus may acquire its methylation pattern before introduction of the tetraprenyl side chain occurs.

$\alpha$-Tocopherolquinone is probably formed by oxidation of $\alpha$-tocopherol, but our specific-radioactivity results neither confirm nor refute this. Thus in numerous experiments with a variety of substrates we have found that $\alpha$-tocopherolquinone always has the same (or marginally higher) specific radioactivity as $\alpha$-tocopherol (Table 6; and Whistance et al. 1967; Threlfall et al. 1968). So far we have attributed this to the two compounds being in rapid equilibrium with each other, but clearly other interpretations are possible.

Specific-radioactivity data support the proposals that in ivy leaves plastoquinone $B$ and plastoquinone $\mathrm{C}$ are produced as a result of the metabolism of plastoquinone. Griffiths, Threlfall \& Goodwin (1968) obtained similar results with tobacco leaves.

Finally we must consider the catabolism of exogenous aromatic amino acids to give compounds capable of entering the biosynthetic sequences that lead to the formation of isoprenoid compounds, i.e. $3 \beta$-hydroxy sterols and the polyprenyl side chains of quinones and chromanols. The two possibilities considered are $(a)$ ring-opening of the molecules with subsequent formation of $\mathrm{C}_{4}$ units and $(b)$ the formation of $\mathrm{C}_{2}$ units from the side chains. The fact that in maize shoots radioactivity from DL[ring. $\left.{ }^{14} \mathrm{C}\right]$ phenylalanine is incorporated into sterols (Table 2) establishes that ring-opening of the aromatic acids does occur. The observation that radioactivity from $\mathrm{DL}-\left[\alpha-{ }^{14} \mathrm{C}\right]$ tyrosine and $\mathrm{DL}$ $\left[\beta-{ }^{14} \mathrm{C}\right]$ tyrosine is incorporated into $3 \beta$-hydroxy sterols but not into fatty acids leads us to suggest that the ring-opening takes place via homogentisic acid in a manner similar to that found in animals (Meister, 1965) and some micro-organisms (Evans, 1963), the acetoacetyl-CoA unit produced being used specifically for isoprenoid biosynthesis. The fact that homogentisic acid dilutes out the incorporation of radioactivity from $\mathrm{DL}-\left[\beta-{ }^{14} \mathrm{C}\right]$ tyrosine into $3 \beta$-hydroxy sterols (Table 5 ) supports this proposal. Since the greatest amounts of radioactivity are found in the extrachloroplastidic components, ring-opening probably takes place more actively outside than inside the chloroplast. In the alga Euglena gracilis extensive ring-opening of exogenous tyrosine appeared to take place (Tables 7 and 9), and no information could be obtained about 
the utilization of tyrosine for quinone and chromanol ring formation.

In maize shoots radioactivity from [side-chain3-14 C]cinnamic acid was incorporated into sterols, suggesting that ring-opening of $\mathrm{C}_{6}-\mathrm{C}_{3}$ phenolic acid can also occur (Table 2). The finding that radioactivity from $p$-hydroxy[U-14C]benzoic acid (a $\mathrm{C}_{6}-\mathrm{C}_{1}$ phenolic acid) is not incorporated into sterols (Whistance et al. 1967) shows that a $\mathrm{C}_{3}$ side chain is a prerequisite for ring-opening.

Acetyl-CoA is probably produced in the conversion of $p$-coumaric acid into $p$-hydroxybenzoic acid (Zenk, 1966). However, any radioactivity in acetylCoA would be expected to undergo dilution in the cell. Indeed no radioactivity was found in fatty acids isolated from maize shoots given $[\alpha-14 \mathrm{C}]$ tyrosine (Table 3).

This work was supported in part by the Science Research Council. G.R.W. was in receipt of an Agricultural Research Council Scholarship. We thank Mr R. W. J. Meredith for expert technical assistance.

\section{REFERENCES}

Bacharach, G. \& Brogan, F. (1928). J. Amer. chem. Soc. 50, 3333.

Bertel, R. (1903). Chem. Zbl.1, 178.

Booth, V. H. (1963). Phytochemistry, 2, 421.

Brown, B. S. (1967). Chem. in Brit. 3, 524.

Bu'Lock, J. D. (1965). The Biosynthesis of Natural Products. London: McGraw-Hill Publishing Co. Ltd.

Campbell, I. M., Cosica, C. J., Kelsey, M. \& Bentley, R. (1967). Biochem. biophys. Res. Commun. 28, 25.

Cox, G. B. \& Gibson, F. (1964). Biochim. biophys. Acta, 93, 204.

Dada, O. A., Threlfall, D. R. \& Whistance, G. R. (1968). Europ. J. Biochem. 4, 329.

Das, B. C., Lounasmaa, M., Tendile, C. \& Lederer, E. (1967). Biochem. biophys. Res. Commun. 26, 211.

Dilley, R. A. \& Crane, F. L. (1963). Analyt. Biochem. 7, 240.

Evans, W. C. (1963). J.gen. Microbiol.32, 177.

Gamborg, O. L. \& Neish, A. C. (1959). Canad. J. Biochem. Physiol. 37, 1277.

Griffiths, W. T. (1967). Biochem. biophys. Res. Commun. 25, 596.

Griffiths, W. T., Threlfall, D. R. \& Goodwin, T. W. (1967). Biochem.J. 103, 589.
Griffiths, W. T., Threlfall, D. R. \& Goodwin, T. W. (1968). Europ.J. Biochem. 5, 124.

Griffiths, W. T., Wallwork, J. C. \& Pennock, J. F. (1966). Nature, Lond., 211, 1037.

Hacking, A. (1967). B.Sc. Thesis: University College of Wales, Aberystwyth.

Hosokawa, K. \& Stanier, R. Y. (1966). J. Amer. chem. Soc. 241, 2453.

Inoue, H., Arai, T. \& Takano, Y. (1958). Chem. Pharm. Bull., Tokyo, 6, 653.

Inoue, H. \& Takano, Y. (1958). Chem. Pharm. Bull., Tokyo, 6, 653.

McCalla, D. R. \& Neish, A. C. (1959). Canad. J. Biochem. Physiol. 37, 531.

Meister, A. (1965). Biochemistry of Amino Acids, vol. 2, pp. 894-908. New York and London: Academic Press Inc.

Nair, P. M. \& Vining, L. C. (1965). Phytochemistry, 4, 401.

Neish, A. C. (1961). Phytochemistry, 1, 1.

Parson, W. W. \& Rudney, H. (1964). Proc. nat. Acad. Sci., Wash., 51, 444.

Pennock, J. F., Hemming, F. W. \& Kerr, J. (1964). Biochem. biophys. Res. Commun. 17, 542.

Pringsheim, E. G. \& Pringsheim, 0. (1952). New Phytol. 51, 65.

Sharma, B. V. S. \& Ramasarma, T. (1967). Biochem. biophys. Res. Commun. 28, 886.

Threlfall, D. R. \& Goodwin, T. W. (1967). Biochem. J. 103, 573.

Threlfall, D. R. \& Griffiths, W. T. (1967). Proc. N.A.T.O. Institute for Advanced Study, Aberystwyth: Biochemistry of Chloroplasts, vol. 2, p. 254. London: Academic Press (Inc.) Ltd.

Threlfall, D. R., Griffiths, W. T. \& Goodwin, T. W. (1967b). Biochem. J. 108, 831.

Threlfall, D. R., Whistance, G. R. \& Goodwin, T. W. (1967a). Biochem. J. 102, 49 P.

Threlfall, D. R., Whistance, G. R. \& Goodwin, T. W. (1968). Biochem. J. 106, 107.

Whistance, G. R. \& Threlfall, D. R. (1967). Biochem. biophys. Res. Commun. 28, 295.

Whistance, G. R., Threlfall, D. R. \& Goodwin, T. W. (1967). Biochem.J. 105, 145.

Whittle, K. J., Audley, B. G. \& Pennock, J. F. (1967). Biochem. J. 103, $21 \mathrm{c}$.

Whittle, K. J., Dunphy, P. J. \& Pennock, J. F. (1966). Biochem. J. 100, 138.

Zenk, M. H. (1966). In Biosynthesis of Aromatic Compounds, p. 45. Ed. by Billek, G. Oxford: Pergamon Press Ltd. 